\title{
Effects of treatment of periparturient dairy cows with recombinant bovine somatotropin on health and productive and reproductive parameters
}

\author{
P. R. B. Silva, ${ }^{*}$ H. F. Soares,† W. D. Braz,† G. D. Bombardelli,† J. A. Clapper,ł D. H. Keisler,§ \\ and R. C. Chebel ${ }^{*}+\# \|^{1}$ \\ *Department of Animal Science, and \\ †Department of Veterinary Population Medicine, University of Minnesota, Saint Paul 55108 \\ ‡Department of Animal Science, South Dakota State University, Brookings 57007 \\ §Division of Animal Science, University of Missouri, Columbia 65211 \\ \#Department of Large Animal Clinical Sciences, and \\ IIDepartment of Animal Sciences, University of Florida, Gainesville 32608
}

\begin{abstract}
The objectives of the current experiment were to evaluate the effects of treating periparturient dairy cows with recombinant bovine somatotropin (rbST) on incidence of postpartum diseases and performance. Holstein (HO) and Jersey (JS) cows from 2 herds were enrolled in the experiment at $253 \pm 3 \mathrm{~d}$ of gestation and assigned to the control $(\mathrm{n}=432)$ and rbST125 $(\mathrm{n}=437)$ treatments. Cows in the rbST125 treatment received $125 \mathrm{mg}$ of rbST, weekly, from -21 to $21 \mathrm{~d}$ relative to calving. Blood sampled weekly, from -21 to $21 \mathrm{~d}$ relative to calving, from a subsample of cows was used to determine the concentrations of growth hormone $(\mathrm{GH}, \mathrm{HO}=106)$ and insulin-like growth factor 1 (IGF-1, HO = 147 and JS = 49). Cows were scored for body condition (BCS) at enrollment and at $1 \pm 3,30 \pm 3$, and $60 \pm 3 \mathrm{~d}$ in milk (DIM). Cows were milked thrice daily and energy-corrected milk (ECM) yield was recorded for the first 30 DIM. Treatment of cows with rbST resulted in greater concentrations of $\mathrm{GH}$ during the prepartum $\left(\log _{10}\right.$ back-transformed concentrations of $\mathrm{GH}$ : $\mathrm{HO}$-control $=7.83$ and $\mathrm{HO}$ rbST125 $=10.36 \mathrm{ng} / \mathrm{mL})$ and postpartum $\left(\log _{10}\right.$ backtransformed concentrations of $\mathrm{GH}$ : HO-control $=10.45$ and HO-rbST125 = $18.47 \mathrm{ng} / \mathrm{mL}$ ) periods. Similarly, IGF-1 concentrations were higher during the prepartum $($ HO-control $=115.1 \pm 4.9$, HO-rbST125 $=137.7$ \pm 4.7, JS-control $=120.2 \pm 8.3$, JS-rbST125 $=167.1$ $\pm 8.1 \mathrm{ng} / \mathrm{mL}$ ) and postpartum (HO-control $=61.3 \pm$ 4.0, HO-rbST125 $=75.2 \pm 3.8$, JS-control $=35.5 \pm$ 6.9 , JS-rbST125 $=54.6 \pm 6.9 \mathrm{ng} / \mathrm{mL}$ ) periods for rbST-
\end{abstract}

Received July 14, 2016.

Accepted November 14, 2016.

${ }^{1}$ Corresponding author: rcchebel@ufl.edu treated cows. During the prepartum period, BCS was not affected by treatment, but during the postpartum period, BCS was reduced for rbST-treated cows (HOcontrol $=3.00 \pm 0.03$, HO-rbST125 $=2.90 \pm 0.03$, JS-control $=2.64 \pm 0.02$, JS-rbST125 $=2.61 \pm 0.02$ ) Cows from the rbST125 treatment tended to have lower incidence of retained fetal membranes $(\mathrm{HO}$-control $=$ 14.3, HO-rbST125 = 6.1, JS-control = 1.5, JS-rbST125 $=1.2 \%$ ) and had reduced incidence of metritis (HOcontrol $=26.2$, HO-rbST125 $=16.6$, JS-control $=19.9$, JS-rbST125 $=13.3 \%$ ) compared with control cows. Ketosis incidence tended to be higher for rbST125 cows $(\mathrm{HO}$-control $=9.4$, HO-rbST125 $=11.3$, JS-control $=$ 8.5, JS-rbST125 $=13.4 \%$ ) compared with control cows. The interaction between treatment and herd tended to affect yield of ECM during the first 30 DIM because HO cows treated with rbST during the periparturient period had greater yield than control HO cows (HO-control $=35.5 \pm 1.0$ vs. HO-rbST125 = $39.4 \pm 1.0 \mathrm{~kg} / \mathrm{d}$ ), but treatment with rbST did not affect yield of ECM of JS cows (JS-control $=26.7 \pm 0.6$ vs. JS-rbST125 $=27.8$ $\pm 0.6 \mathrm{~kg} / \mathrm{d})$. Treatment of periparturient dairy cows with $125 \mathrm{mg}$ of rbST decreased the incidence of uterine disorders in HO and JS cows and increased yield of ECM during the first 30 DIM among HO cows, despite slightly increasing the incidence of ketosis.

Key words: dairy cow, somatotropin, health, performance

\section{INTRODUCTION}

Feed intake of dairy cows is reduced by approximately $30 \%$ from the beginning of the dry period to the last week before calving (Hayirli et al., 1998). The decreased feed intake combined with the increased energy demands from the nonlactating to the lactating state, an increase of approximately $13 \mathrm{Mcal} / \mathrm{d}$ of net energy for lactation (NRC, 2001), results in negative energy 
balance (NEB) from late gestation up to 10 to $12 \mathrm{wk}$ postpartum (Bertics et al., 1992; Grummer, 1995). In periods of NEB, dairy cows have increased concentrations of growth hormone (GH), coupled with insulin resistance, that are associated with a coordinated increase in lipolysis and a decrease in glucose uptake and oxidation by peripheral tissues so that nutrients are more readily available for lactogenesis (Bell and Bauman, 1997). Severe NEB, however, leads to excessive lipolysis and elevated concentrations of fatty acids in the plasma, which may predispose cows to hepatic lipidosis, compromised liver function, and elevated plasma BHB concentrations due to incomplete fatty acid oxidation (Grummer et al., 2004). Under these conditions, periparturient cows may develop metabolic disorders such as fatty liver, ketosis, and displacement of abomasum (Oetzel, 2004). Periparturient dairy cows are also predisposed to infectious diseases (Cai et al., 1994; Kimura et al., 2002; Hammon et al., 2006) because hormonal changes (Burton et al., 1995; Moreira da Silva et al., 1998), shortages in major energetic fuels and minerals (Kehrli et al., 1989a,b; Kimura et al., 2006), and elevated concentrations of fatty acids and products of oxidative stress (i.e., reactive oxygen species; Contreras et al., 2012) alter the structure and function of immune cells (Kehrli et al., 1989a,b). Therefore, it is not surprising that approximately $75 \%$ of health disorders in dairy cows (e.g., milk fever, ketosis, retained fetal membranes, metritis, mastitis, and displacement of abomasum) are diagnosed in the first $30 \mathrm{~d}$ postpartum (LeBlanc et al., 2006). Strategies that improve immune function and glucose and lipid metabolism of periparturient dairy cows may reduce the incidences of infectious and metabolic diseases.

Treatment of dairy cows with recombinant bST $(\mathbf{r b S T})$ is associated with increased liver gluconeogenesis, suppression of insulin's inhibitory effect on gluconeogenesis (Peel and Bauman, 1987), and increased complete oxidation of fatty acids in bovine liver slices (Pocius and Herbein, 1986). Although treatment of periparturient cows with rbST may increase glucose availability for lactogenesis and other key functions, such as immune competence, its effects on health and productive responses are variable. Cows treated with $500 \mathrm{mg}$ of rbST every $14 \mathrm{~d}$ during the prepartum period had increased DMI and glucose concentration, reduced concentrations of fatty acids and BHB around the time of calving, and greater milk yield in the first $42 \mathrm{~d}$ of lactation compared with control cows (Putnam et al., 1999). In contrast, Jersey cows treated with $500 \mathrm{mg}$ of rbST every $14 \mathrm{~d}$ from -28 to $14 \mathrm{~d}$ postpartum had reduced fat-corrected milk yield (Eppard et al., 1996). Cows treated with $325 \mathrm{mg}$ of rbST every $14 \mathrm{~d}$ during the prepartum period had increased glucose concentration during the peripartum period, but no differences in DMI, incidence of postpartum diseases, or reproductive performance were observed (Gohary et al., 2014). A low dose of rbST (142.8 mg) given every $14 \mathrm{~d}$ from -21 to 42 d postpartum increased peripartum concentrations of IGF-1, glucose, and insulin; increased milk yield; and decreased the incidences of ketosis, mastitis, and digestive problems (Gulay et al., 2003, 2004, 2007). The effects of rbST treatment of periparturient dairy cows on incidences of retained fetal membranes and metritis are more controversial (Eppard et al., 1996; Putnam et al., 1999; Gulay et al., 2007; Gohary et al., 2014), perhaps because some of the cited experiments lacked appropriate sample size or because of differences in rbST treatment frequency and dose.

Insulin-like growth factor 1 stimulates growth, differentiation, and functionality of several cell types, including immune cells (Heemskerk et al., 1999). In a recent experiment, treatment of Holstein cows with $125 \mathrm{mg}$ of rbST, every $7 \mathrm{~d}$, from -21 to $28 \mathrm{~d}$ relative to calving, increased IGF-1 concentrations, increased the intensity of expression of adhesion molecule, the intensity of phagocytosis and oxidative burst by PMNL, and the concentration of IgG anti-ovalbumin (Silva et al., 2015). Furthermore, cows treated with $125 \mathrm{mg}$ of rbST had reduced incidence of metritis compared with control cows and tended to produce more milk during wk 3 and 5 of lactation than control cows (Silva et al., 2015). The hypotheses of the current experiment were that weekly treatment of periparturient dairy cows from -21 to $21 \mathrm{~d}$ relative to calving with 125 $\mathrm{mg}$ of rbST would decrease the incidence of infectious (e.g., metritis and mastitis) and metabolic (e.g., ketosis and displacement of abomasum) diseases, improve cow survival and reproductive performance, and increase yield of energy-corrected milk and milk components during the first $30 \mathrm{~d}$ of lactation. Objectives of the current experiment were to evaluate the effects of rbST treatment of periparturient dairy cows on postpartum health and reproductive and productive performances. In this experiment, we explored a new strategy of rbST treatment, with more frequent applications (weekly) and reduced doses $(125 \mathrm{mg}$ ) than previously published research (Eppard et al., 1996; Putnam et al., 1999; Gulay et al., 2004, 2003, 2007; Gohary et al., 2014).

\section{MATERIALS AND METHODS}

The procedures conducted during this experiment were approved by the Institutional Animal Care and Use Committee from the University of Minnesota (protocol \#1505-32580A). 


\section{Animals, Housing, and Nutrition}

Pregnant cows $(\mathrm{n}=869)$ from 2 herds (Holstein, HO, nulliparous $=54$ and parous $=267$; Jersey, JS, nulliparous $=210$ and parous $=338$ ) were enrolled in the experiment at $253 \pm 3 \mathrm{~d}$ of gestation $(-28 \mathrm{~d}$ relative to calving). Holstein cows from a commercial freestall dairy herd located in northwest Wisconsin were housed in a naturally ventilated freestall barn from $253 \mathrm{~d}$ of gestation to $21 \mathrm{~d}$ postpartum. A TMR was fed once a day at $0900 \mathrm{~h}$ from enrollment to calving and at 0400 $\mathrm{h}$ from calving to $21 \mathrm{~d}$ postpartum. Jersey cows from a commercial freestall dairy herd located in south-central Minnesota were housed in cross-ventilated barns from $253 \mathrm{~d}$ of gestation to $21 \mathrm{~d}$ postpartum. A TMR was fed once a day at $0400 \mathrm{~h}$ from enrollment to calving and at $0800 \mathrm{~h}$ from calving to $21 \mathrm{~d}$ postpartum. In both herds, nulliparous and parous animals were fed different diets during the prepartum period and housed in separate pens during the prepartum and postpartum periods. After parturition, primiparous and multiparous cows were fed the same diet in the HO herd and different diets in the JS herd. The composition of the TMR fed in the prepartum ( -21 to calving) and postpartum (1 to $21 \mathrm{~d}$ postpartum) periods is presented in Table 1 .

In both herds, cows that demonstrated signs of calving (discomfort, restlessness, tail twitching, and visualization of the allantoic sac through the vulva) were moved to a box stall. Within $12 \mathrm{~h}$ after calving, cows were moved to a postpartum pen (1 to $21 \mathrm{~d}$ postpartum) for daily observation and diagnosis of postpartum diseases. At approximately $21 \mathrm{~d}$ postpartum, approximately half of the Jersey cows were moved to another herd that was located 8 miles away from the herd in which cows were housed.

\section{Treatments}

At enrollment ( -28 d relative to calving), all cows (Holsteins and Jerseys) were scored for body condition (Ferguson et al., 1994) and locomotion (Sprecher et al., 1997). Cows with BCS $\geq 2.25$ and locomotion score $\leq 2$ were balanced for parity (nulliparous vs. parous), BCS, previous lactation 305-d mature-equivalent milk yield (parous), and previous lactation interval from calving to conception (parous) and were assigned randomly to 1 of 2 treatments: untreated control $(\mathrm{n}=432)$ or rbST125 ( $\mathrm{n}=437)$. Cows assigned to the rbST125 treatment received $125 \mathrm{mg}$ of rbST (Posilac, sometribove zinc suspension for injection; Elanco Animal Health, Greenfield, IN) every $7 \mathrm{~d}$ from -21 to $21 \mathrm{~d}$ relative to calving. The dose and frequency of rbST treatment used in the current experiment was chosen based on the results from Silva et al. (2015), which demonstrated that a dose of $125 \mathrm{mg}$ of rbST resulted in significantly improved immune responses compared with untreated control and $87.5 \mathrm{mg}$ of rbST. Injections were given subcutaneously in the neck area (HO herd) or in the ischiorectal depression (JS herd), using 1-mL tuberculin syringes with 16-gauge and 1.6-cm-long hypodermic needles. Syringes containing $125 \mathrm{mg}$ of $\mathrm{rbST}$ were prepared 6 to $12 \mathrm{~h}$ before treatment. The contents of commercially available syringes of rbST (Posilac, sometribove zinc suspension for injection; Elanco Animal Health) were dispensed into sterile containers, and the appropriate volume of rbST was aspirated into ster-

Table 1. Composition (\% of DM unless otherwise noted) of TMR offered to prepartum ( $-21 \pm 3$ to $0 \mathrm{~d}$ relative to calving) and postpartum (1 to $21 \pm 3$ d postpartum) cows

\begin{tabular}{|c|c|c|c|c|c|c|c|c|}
\hline \multirow{2}{*}{ Item } & \multicolumn{4}{|c|}{ Holstein herd } & \multicolumn{4}{|c|}{ Jersey herd } \\
\hline & \multicolumn{2}{|c|}{ Parous } & \multicolumn{2}{|c|}{ Nulliparous } & \multicolumn{2}{|c|}{ Parous } & \multicolumn{2}{|c|}{ Nulliparous } \\
\hline DM, \% & 50.36 & 49.93 & 47.75 & 49.93 & 47.07 & 48.11 & 46.76 & 46.69 \\
\hline $\mathrm{NE}_{\mathrm{L}}, \mathrm{Mcal} / \mathrm{kg}$ & 1.44 & 1.64 & 1.42 & 1.64 & 1.47 & 1.64 & 1.36 & 1.60 \\
\hline $\mathrm{CP}$ & 14.12 & 15.46 & 13.79 & 15.46 & 15.89 & 18.66 & 14.72 & 16.01 \\
\hline Ether extract & 2.62 & 3.59 & 2.60 & 3.59 & 3.5 & 4.40 & 2.96 & 3.50 \\
\hline Ash & 9.24 & 7.87 & 8.72 & 7.87 & 9.79 & 8.71 & 11.08 & 8.13 \\
\hline Calcium & 1.35 & 0.91 & 0.99 & 0.91 & 1.48 & 1.26 & 1.29 & 1.13 \\
\hline Phosphorus & 0.35 & 0.47 & 0.37 & 0.47 & 0.39 & 0.37 & 0.38 & 0.47 \\
\hline Magnesium & 0.32 & 0.30 & 0.31 & 0.30 & 0.43 & 0.29 & 0.40 & 0.32 \\
\hline Potassium & 1.09 & 1.33 & 1.13 & 1.33 & 1.25 & 1.85 & 1.18 & 1.38 \\
\hline Sulfur & 0.29 & 0.34 & 0.22 & 0.34 & 0.44 & 0.34 & 0.43 & 0.35 \\
\hline
\end{tabular}


ile syringes that were kept refrigerated. The syringes were warmed to room temperature $\left(15\right.$ to $\left.30^{\circ} \mathrm{C}\right)$ before rbST administration.

\section{Blood Sampling and GH, IGF-1, Glucose, Fatty Acids, BHB, and Calcium Concentrations}

Blood was sampled weekly from $-28 \pm 3$ to $24 \pm 3$ $\mathrm{d}$ relative to calving from $106 \mathrm{HO}$ cows to determine the concentrations of $\mathrm{GH}$, and from $147 \mathrm{HO}$ and $49 \mathrm{JS}$ cows to determine the concentrations of IGF-1, glucose, fatty acids, and BHB. Insulin concentration was determined in samples collected weekly from $-28 \pm 3$ to 24 $\pm 3 \mathrm{~d}$ relative to calving from $32 \mathrm{HO}$ and 28 JS cows. Within weekly cohort of cows enrolled in the experiment, cows were randomly selected for blood sampling. Cows sampled were balanced for parity (primiparous vs. multiparous) and BCS at enrollment.

Cows were restrained in self-locking stanchions during feeding and blood samples were collected from the coccygeal vein/artery using 22 -gauge and 2.5 -cm-long needles into empty evacuated tubes and into evacuated tubes that contained $\mathrm{K}_{2}$ EDTA and evacuated tubes that did not contain anticoagulant (Becton Dickinson Vacutainer Systems, Franklin Lakes, NJ). Tubes were placed in ice until centrifugation $(1,200 \times g$ for 15 min at $4^{\circ} \mathrm{C}$ ) for serum or plasma separation within $8 \mathrm{~h}$ after blood samples were collected. Serum and plasma were aliquoted into microcentrifuge tubes and stored at $-32^{\circ} \mathrm{C}$ until analysis.

Serum GH concentrations were determined in triplicate using a modified RIA from an ovine GH assay (Lalman et al., 2000). Serum IGF-1 concentrations were quantified using a commercially available kit (Human IGF-1 Quantikine ELISA; R\&D Systems Inc., Minneapolis, MN). The intra- and interassay coefficients of variation $(\mathbf{C V})$ for the GH and IGF-1 assays were $<5 \%$. Plasma concentrations of fatty acids were determined using a colorimetric assay (Wako Chemicals USA, Richmond, VA; Ballou et al., 2009) and plasma concentrations of BHB were determined enzymatically (Ranbut, Randox Laboratories, Antrim, UK; Ballou et al., 2009). Control serum (Randox Control Sera) was used for the fatty acid and BHB assays. The intraassay CV were 7 and $10 \%$ for the fatty acid and BHB assays, respectively, and the interassay $\mathrm{CV}$ were 11 and $8 \%$ for the fatty acid and BHB assays, respectively. Plasma glucose concentration was determined by enzymatic reaction (Stanbio Laboratory, Boerne, TX). The intraand interassay CV were 4 and $3 \%$, respectively. Insulin was analyzed using a commercial ELISA kit for bovine insulin (Mercodia Bovine Insulin ELISA, Mercodia Inc., Uppsala, Sweden). The intra- and interassay CV were 5.2 and $9.4 \%$.
One hundred six cows ( $\mathrm{n}=53$ /treatment $)$ had blood sampled within the first $72 \mathrm{~h}$ postpartum. These samples were used to determine serum total calcium concentrations using an automated chemistry analyzer (RX Daytona ${ }^{+}$, Randox Laboratories Ltd.).

\section{BCS and Locomotion Score}

All cows from the HO herd were scored for body condition ( $1=$ emaciated and $5=$ obese; 0.25 -unit increments; Ferguson et al., 1994) at enrollment and on d $1 \pm 3,30 \pm 3$, and $60 \pm 3$ postpartum. In the Jersey herd, all cows were scored for body condition at enrollment and on $\mathrm{d} 1 \pm 3$ postpartum, and 326 and 290 cows were scored for body condition at $30 \pm 3$ and $60 \pm 3 \mathrm{~d}$ postpartum, respectively.

In both herds, cows were scored for locomotion $(1=$ normal locomotion and $5=$ severely lame; as described by Sprecher et al., 1997) at enrollment. In the JS herd, all cows were scored for locomotion at $1 \pm 3 \mathrm{~d}$ postpartum and 326 and 290 cows were scored for locomotion at $30 \pm 3$ and $60 \pm 3$ d postpartum, respectively. Cows with a locomotion score $>2$ were considered lame. Within herd, body condition and locomotion were scored by the same individual throughout the experiment. These individuals were unaware of the treatment of cows during the scoring.

\section{Clinical Examination and Disease Definition}

Subclinical hypocalcemia was defined as serum total calcium concentrations between 5.5 and $8.0 \mathrm{mg} / \mathrm{dL}$ (Goff, 2008) within $72 \mathrm{~h}$ postpartum. Farm personnel were trained to examine cows within $24 \mathrm{~h}$ after calving to diagnose and record the occurrence of retained fetal membranes (Kelton et al., 1998). Study personnel palpated cows per rectum on $\mathrm{d} 4 \pm 1,7 \pm 1,10 \pm 1$, and $13 \pm 1$ postpartum for the diagnosis of metritis. Metritis was defined as cows having watery, pink/brown, and fetid uterine discharge (LeBlanc, 2010). In the JS herd, metritic cows were further examined and those with rectal temperature $>39.5^{\circ} \mathrm{C}$, anorexia, or depression were considered to have acute metritis (LeBlanc, 2010). Three hundred twenty-five JS cows were examined for vaginal purulent discharge (vaginal exudate consisting of $\geq 50 \%$ of pus) using the Metricheck device (Simcro, Hamilton, New Zealand; McDougall et al., 2007) on d $35 \pm 3$ postpartum.

Cow-side tests for whole-blood BHB concentrations were performed for all cows on $\mathrm{d} 7 \pm 3$ and $14 \pm 3$ postpartum using handheld meters (PX; Precision Xtra, Abbott Diabetes Care Inc., Alameda, CA) to determine incidence of ketosis. Ketosis was defined as at least one sample with $\mathrm{BHB}$ concentration $\geq 1,400 \mu \mathrm{mol} / \mathrm{L}$ 
(Duffield et al., 2009). All cows were observed once daily by farm personnel for displacement of abomasum and thrice daily during milking for mastitis. Mastitis was defined as altered milk and redness and firmness of the udder. Displacement of abomasum was defined as a metallic sound during auscultation and percussion between the 7th and 13th intercostal space on the left or right side. Incidences of displacement of abomasum and mastitis within $60 \mathrm{~d}$ postpartum were recorded. Percentage of cows removed from the herd (death/culling) during the first $60 \mathrm{~d}$ postpartum was calculated.

Farm personnel responsible for health evaluations were blinded to treatments. Despite the fact that study personnel were not blinded to treatments, at the time of clinical exams and BHB concentration determination, treatments of the cows were not known. Treatment with rbST was not done on the same day as when cows were being examined to prevent bias.

\section{Milk Yield and Milk Components}

Cows were milked thrice daily. The DHIA was hired by the investigators to measure milk yield, milk fat and protein contents, and SCC weekly from $5 \pm 3$ to $32 \pm 3 \mathrm{~d}$ postpartum from all $\mathrm{HO}$ cows. During the remainder of the lactation, milk yield was determined once monthly by the inline milk system. At the onset of the experiment, milk yield, milk fat and protein contents, and SCC were being determined monthly in the JS herd during the official DHIA test. However, approximately 4 mo after the start of the experiment, the official DHIA test ceased and no milk yield data were recorded. Furthermore, starting at $49 \pm 3$ DIM, all cows were treated with $500 \mathrm{mg}$ of rbST (Posilac, sometribove zinc suspension for injection; Elanco Animal Health) every $11 \mathrm{~d}$ in the HO herd and every 10 $\mathrm{d}$ in the JS herd. Therefore, production parameters during the first month of lactation are reported herein. Energy-corrected milk was calculated for each cow using the following formula (Orth, 1992):

$$
\begin{gathered}
\operatorname{ECM}(\mathrm{kg})=[(\mathrm{kg} \text { of milk }) \times 0.327]+[(\mathrm{kg} \text { of fat }) \\
\times 12.95]+[(\mathrm{kg} \text { of protein }) \times 7.2] .
\end{gathered}
$$

Linear SCC was calculated for each cow using the formula from Shook (1982): Linear SCC $=[\operatorname{Ln}$ (SCC per $\mathrm{mL} \div 100) \div 0.6931]+3$.

\section{Reproductive Management and Parameters}

Holstein cows had their estrous cycle presynchronized with 2 injections of $\mathrm{PGF}_{2 \alpha}$ (23-36 and 37-50 DIM) and were enrolled in the Ovsynch protocol with a CIDR in- sert (controlled internal drug release device containing $1.38 \mathrm{~g}$ of progesterone; Zoetis Animal Health, Florham Park, NJ) at 48 to 61 DIM (d 0: GnRH and CIDR, d 7: PGF $_{2 \alpha}$ and CIDR removal, d 9: GnRH, and, 12 to $14 \mathrm{~h}$ later, timed $\mathrm{AI}$ ). The voluntary waiting period in the HO herd was 50 DIM. Cows were treated with $\mathrm{GnRH}$ at $32 \pm 3 \mathrm{~d}$ after $\mathrm{AI}$ and examined for pregnancy $39 \pm 3 \mathrm{~d}$ after AI by manual palpation of the uterine contents per rectum. Pregnant cows were reexamined for pregnancy at $66 \pm 3$ and $178 \pm 3 \mathrm{~d}$ after AI. Cows diagnosed not pregnant at $39 \pm 3 \mathrm{~d}$ after AI were treated with $\mathrm{PGF}_{2 \alpha}$ on the same day, GnRH $2 \mathrm{~d}$ later, and were re-inseminated at fixed time 12 to $14 \mathrm{~h}$ after the GnRH treatment. Non-sex-sorted semen was used for all inseminations in the HO herd.

Jersey cows were presynchronized with 3 injections of $\mathrm{PGF}_{2 \alpha}$ at $39 \pm 3,53 \pm 3$, and $67 \pm 3$ DIM. Cows were observed daily for signs of estrus (removal of tail paint) and inseminated if observed in estrus after the voluntary waiting period (40 DIM). Cows not observed in estrus by $79 \pm 3$ DIM were enrolled in the 5-d Cosynch protocol (d 0: GnRH, d 5: $\mathrm{PGF}_{2 \alpha}$, d 6: $\mathrm{PGF}_{2 \alpha}, \mathrm{d}$ 8: GnRH and TAI). Cows not re-inseminated in estrus were examined for pregnancy by transrectal ultrasound (5-MHz probe, E. I. Medical, Loveland, CO) at $31 \pm 3 \mathrm{~d}$ after AI. Pregnant cows were re-examined at $66 \pm 3$ and $178 \pm 3 \mathrm{~d}$ after AI by manual palpation of the uterine contents per rectum. Cows diagnosed not pregnant at $31 \pm 3 \mathrm{~d}$ after AI that had a corpus luteum received a $\mathrm{PGF}_{2 \alpha}$ injection 2 d later and, if not re-inseminated in estrus within 12 d, were submitted to the 5-d Cosynch protocol for reinsemination at fixed time. Cows diagnosed not pregnant at $31 \pm 3 \mathrm{~d}$ after $\mathrm{AI}$ that did not have a corpus luteum received a $\mathrm{GnRH}$ injection on the same day and, if not re-inseminated within $7 \mathrm{~d}$, were submitted to the 5-d Cosynch protocol for re-insemination at fixed time. Sexed semen was used for the first and second inseminations of JS cows observed in estrus, whereas non-sex-sorted semen was used for insemination of cows at a fixed time.

Percentage of cows receiving first and second postpartum AI at detected estrus, pregnancy per AI (P/ AI) after first and second postpartum AI, percentage of cows with pregnancy loss between the first and second pregnancy exams following the first and second postpartum AI, and pregnancy rate up to 150 DIM were calculated.

\section{Statistical Analysis}

The experiment had a complete randomized design with animals paired according to parity (nulliparous vs. parous), BCS, previous lactation 305-d mature-equiva- 
lent milk yield (parous), and previous lactation interval from calving to conception (parous). Sample sizes were calculated based on results from a previous experiment (Silva et al., 2015) to provide sufficient power to determine statistical significances while preventing type I ( $\alpha$ $=0.05)$ and type II $(1-\beta=0.80)$ errors. Therefore, a sample size of 400 cows/treatment would be sufficient to demonstrate statistical significance when the incidences of metritis and ketosis differ by 8 and 6 percentage units, respectively, between treatments. Furthermore, 400 cows/treatment would be sufficient to demonstrate statistical significance when milk yield differs by 1.6 $\mathrm{kg} / \mathrm{d}$ between treatments and standard deviation of milk yield is $9 \mathrm{~kg} / \mathrm{d}$. Furthermore, a subsample of 50 cows/treatment would be sufficient to demonstrate statistical significance when GH concentration differs by 5 $\mathrm{ng} / \mathrm{mL}$ between treatments and standard deviation for $\mathrm{GH}$ concentration is $12 \mathrm{ng} / \mathrm{mL}$. Similarly, 100 cows/ treatment would be sufficient to demonstrate statistical significance when IGF-1 concentration differs by 17.5 $\mathrm{ng} / \mathrm{mL}$ between treatments and standard deviation of IGF-1 concentration is $51 \mathrm{ng} / \mathrm{mL}$.

Cows assigned to the $\operatorname{rbST} 125$ treatment that received $<2$ treatments of $\mathrm{rbST}$ and control cows that calved within less than 2 wk after being moved to the prepartum pen were removed from the experiment and statistical analyses. All statistical analyses were conducted using SAS version 9.4 (SAS Institute Inc., Cary, $\mathrm{NC}$ ). In all models, cows were used as the experimental unit.

Continuous data were assessed for normality of residuals. Continuous data with residuals not normally distributed were $\log _{10}$ or square-root transformed. Continuous data without repeated measurements (BCS and lactation number at enrollment, previous lactation 305-d mature-equivalent milk yield, and calving to pregnancy interval, and number of days that cows stayed in the prepartum pen) were analyzed by ANOVA using the GLM procedures of SAS. The models included treatment (control vs. rbST125), herd (HO vs. JS), and the interaction between treatment and herd as fixed effects. Milk yield and milk components in the first $30 \mathrm{~d}$ postpartum were analyzed by ANOVA using the GLM procedures of SAS. The models included treatment, herd, parity (nulliparous vs. parous), BCS at enrollment, and their interactions with treatment. Nonsignificant variables $(P>0.10)$ were removed from the models in a backward stepwise elimination procedure.

The MIXED procedure of SAS was used to analyze continuous data with repeated measurements (GH, IGF-1, glucose, insulin, fatty acids, BHB, and BCS). The prepartum and postpartum periods were analyzed separately. For analyses of repeated measurements, the repeated statement was used and the model included treatment, time, the interaction between treatment and time, herd, the interaction between treatment and herd, and BCS at enrollment as fixed effects. Cow was included as the random effect and cows were nested within treatment. When concentrations of hormones and metabolites differed between treatments on $\mathrm{d}-21$ relative to calving, the concentration on $\mathrm{d}-21$ relative to calving was used as a covariate. The structure of covariance (auto-regressive, unstructured, or compound symmetry) was chosen according to the Bayesian information criteria.

Dichotomous data were analyzed by logistic regression using the LOGISTIC procedure of SAS to obtain adjusted odds ratio and their respective confidence intervals. Variables included in the logistic regression models were treatment, herd, parity, BCS at enrollment, and their interactions with treatment. Nonsignificant $(P>0.10)$ variables were removed by a backward stepwise elimination procedure based on Wald's statistics criterion.

The hazard of pregnancy up to $150 \mathrm{~d}$ postpartum was analyzed by the Cox proportional hazards regression using the PHREG procedure of SAS. The model included treatment, herd, parity, BCS at enrollment, and their interaction with treatment. Nonsignificant $(P$ $>0.10$ ) variables were removed by a backward stepwise elimination procedure based on the Wald's statistics criterion. The difference between treatments in the interval from calving to establishment of pregnancy was evaluated by the Kaplan-Meier survival analysis using the LIFETEST procedure of SAS. Cows were censored when they did not conceive and left the herd (death/ culling) before 150 DIM or when they reached 150 DIM without conceiving. Statistical significance was defined as $P \leq 0.05$ and trends were considered if $0.05<P \leq$ 0.10 .

\section{RESULTS}

Forty-five cows were removed from the study and statistical analyses (HO-control $=6, \mathrm{HO}-\mathrm{rbST} 125=13$, JS-control $=11$, and JS-rbST125 = 15) for the following reasons: diagnosed not pregnant after enrollment $($ control $=1, \operatorname{rbST} 125=3), \operatorname{rbST} 125$ cows that calved before receiving at least 2 treatments of $\operatorname{rbST}(\mathrm{n}=12)$, control cows that calved $<2$ wk after enrollment $(\mathrm{n}=$ 7 ), cows that calved $>5 \mathrm{wk}$ after enrollment (control $=7, \operatorname{rbST} 125=10)$, abortion $($ control $=1)$, injury $(\operatorname{rbST} 125=1)$, and death before calving (control = $1, \operatorname{rbST} 125=2$ ). Eight hundred and twenty-four cows remained in the experiment $(\mathrm{HO}-$ control $=151$, HO$\operatorname{rbST} 125=151$, JS-control $=264$, and JS-rbST125 $=$ 258). 
Average lactation number $(P=0.92)$ and the percentages of nulliparous $(P=0.92)$, lactation $=1(P=$ $0.99)$, lactation $=2(P=0.63)$, and lactation $\geq 3(P$ $=0.78$ ) cows enrolled in the experiment did not differ between treatments (Table 2). At enrollment, BCS ( $P$ $=0.62$ ), previous lactation 305-d mature-equivalent milk yield $(P=0.28)$, and previous lactation interval from calving to pregnancy $(P=0.90)$ did not differ between treatments (Table 2). The average number of days that cows stayed in the prepartum pen was not different between treatments $(P=0.28$; Table 2$)$. The percentages of cows calving male calves $(P=0.51)$ and twins $(P=0.17)$ were not different between treatments (Table 2).

\section{Effects of Treatment on Hormones of the Somatotropic Axis and Metabolites}

Holstein cows treated weekly with $125 \mathrm{mg}$ of $\mathrm{rbST}$ had greater concentrations of GH prepartum $(P<0.01)$ and postpartum $(P<0.01)$ compared with control cows (Figure 1). The $\log _{10}$ back-transformed concentrations of $\mathrm{GH}$ were 7.83 and $10.36 \mathrm{ng} / \mathrm{mL}$ during the prepartum period and 10.45 and $18.47 \mathrm{ng} / \mathrm{mL}$ during the postpartum period for control and rbST125 cows, respectively. Similarly, rbST125 cows had higher prepartum $(P<$ $0.01)$ and postpartum $(P<0.01)$ IGF-1 concentrations than control cows (Figure 2). Prepartum $(P=0.56)$ and postpartum $(P=0.81)$ glucose concentrations were not affected by treatment (Figure 3). Insulin concentration during the prepartum period was not affected by treatment $\left(P=0.89 ; \log _{10}\right.$ back-transformed insulin concentrations: HO-control $=0.76, \mathrm{HO}-\mathrm{rbST} 125=0.76$, JS-control $=0.44$, JS-rbST125 $=0.42 \mu \mathrm{U} / \mathrm{L}$; Figure 4). Although treatment did not affect $\left(P=0.69\right.$; $\log _{10}$ backtransformed insulin concentrations: HO-control $=0.18$, HO-rbST125 $=0.19$, JS-control $=0.18$, JS-rbST125 $=$ $0.16 \mu \mathrm{U} / \mathrm{L}$ ) insulin concentration during the postpartum period, the interaction between treatment and day relative to calving tended $(P=0.09)$ to affect insulin concentration. On d 4 , there was a tendency $(P=0.10)$ for rbST125 cows to have greater insulin concentration than control cows, but on d 25, insulin concentration was $(P=0.05)$ greater for control cows than rbST125 cows (Figure 4). Treatment did not affect fatty acid concentrations during the prepartum $\left(P=0.14 ; \log _{10}\right.$ back-transformed fatty acid concentrations: HO-control $=190.2$, HO-rbST125 = 206.0, JS-control $=113.3$, JS$\operatorname{rbST} 125=135.5 \mu \mathrm{mol} / \mathrm{L})$ and postpartum $(P=0.20$; $\log _{10}$ back-transformed fatty acid concentrations: HOcontrol $=414.0$, HO-rbST125 $=439.6$, JS-control $=$ 214.4, JS-rbST125 $=257.3 \mu \mathrm{mol} / \mathrm{L}$ ) periods (Figure 5 ). Prepartum $\left(P=0.39\right.$; $\log _{10}$ back-transformed BHB concentrations: HO-control $=344.5$, HO-rbST125 $=340.3$,

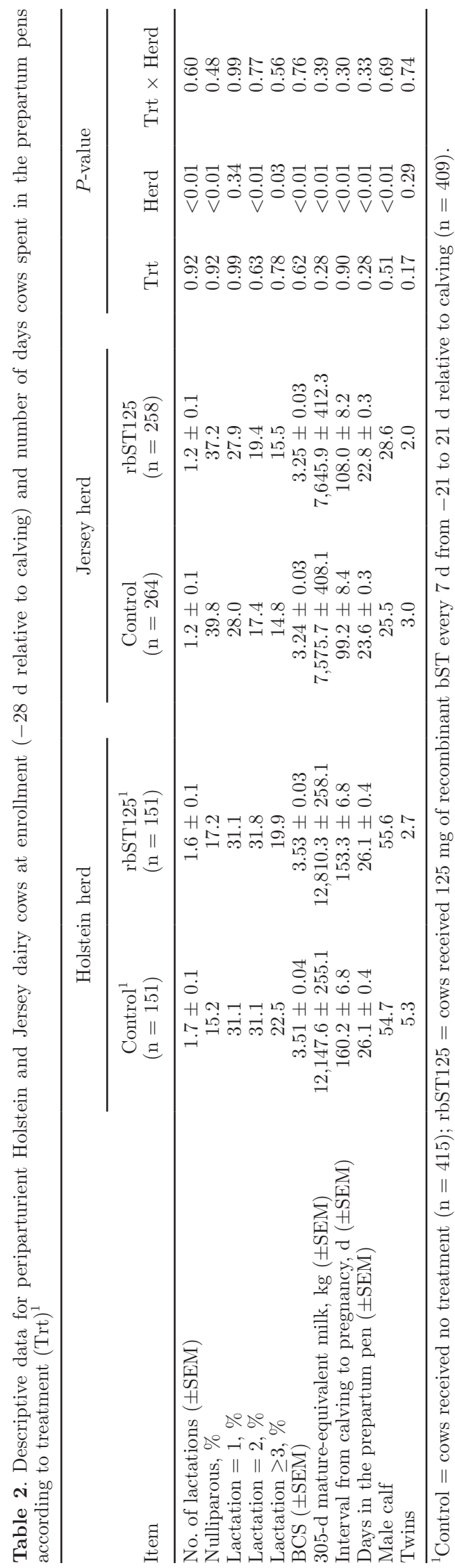




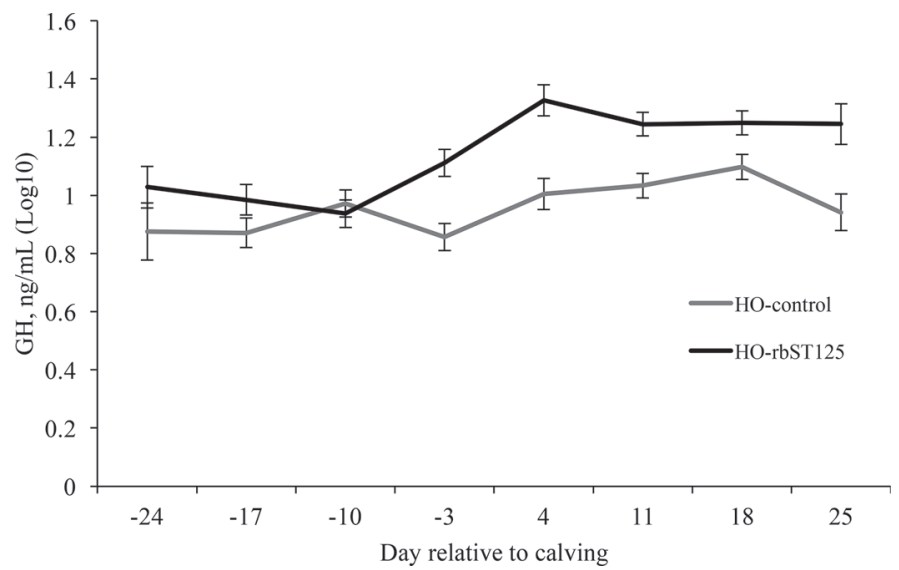

Figure 1. Growth hormone (GH) concentration of Holstein (HO) cows according to treatment and day relative to calving. Treatments: control $=$ cows received no treatment; rbST $125=$ cows received 125 $\mathrm{mg}$ of recombinant bST every $7 \mathrm{~d}$ from -21 to $21 \mathrm{~d}$ relative to calving. Prepartum period: Treatment, $P<0.01$; day relative to calving, $P=$ 0.72 ; and the interaction between treatment and day relative to calving, $P=0.02$. Postpartum period: Treatment, $P<0.01$; day relative to calving, $P=0.76$; and the interaction between treatment and day relative to calving, $P=0.25$. Results are reported as LSM $( \pm$ SEM) of the $\log _{10}$ analysis.

JS-control $=499.3$, JS-rbST125 $=463.2 \mu \mathrm{mol} / \mathrm{L})$ and postpartum $\left(P=0.36 ; \log _{10}\right.$ back-transformed BHB concentrations: HO-control $=607.9$, HO-rbST125 $=$ 569.0, JS-control $=592.0, \mathrm{JS}-\mathrm{rbST} 125=610.9 \mu \mathrm{mol} / \mathrm{L}$ ) plasma BHB concentrations were not affected by treatment (Figure 6).

\section{Effects of Treatment on BCS, Incidence of Postpartum Diseases, and Removal from the Herd Within 60 DIM}

Although treatment did not affect prepartum BCS $(P=0.93)$, control cows had $(P=0.01)$ higher BCS on d 30 and 60 postpartum than rbST125 cows (Figure $7)$. Treatment did not $(P=0.65)$ affect the incidence of stillbirth, but the interaction between treatment and herd tended to affect $(P=0.09)$ the incidence of stillbirth because HO-rbST125 cows had reduced incidence of stillbirth compared with HO-control cows, whereas JS-rbST125 cows had greater incidence of stillbirth than JS-control cows (Table 3).

Incidence of subclinical hypocalcemia was not $(P=$ 0.20 ) affected by treatment (Table 3 ). Cows from the rbST125 treatment tended $(P=0.08)$ to have reduced incidence of retained fetal membranes compared with control cows (Table 3 ). Furthermore, rbST125 cows had $(P<0.01)$ reduced incidence of metritis compared with control cows (Table 3). Among JS cows, treatment did not affect the incidences of acute metritis $(P=0.15)$ and vaginal purulent discharge $35 \pm 3 \mathrm{~d}$ postpartum $(P$ $=0.91 ;$ Table 3 ).

Incidence of ketosis tended $(P=0.08)$ to be greater for the rbST125 treatment compared with the control treatment (Table 3). No differences between treatments regarding the incidences of displacement of abomasum $(P=0.80)$ and mastitis $(P=0.18)$ within 60 DIM were observed (Table 3). Among JS cows, incidence of lameness at $1 \pm 1(P=0.76), 30 \pm 3(P=0.42)$ and $60 \pm 3(P=0.33) \mathrm{d}$ postpartum were not affected by treatment (Table 3$)$.

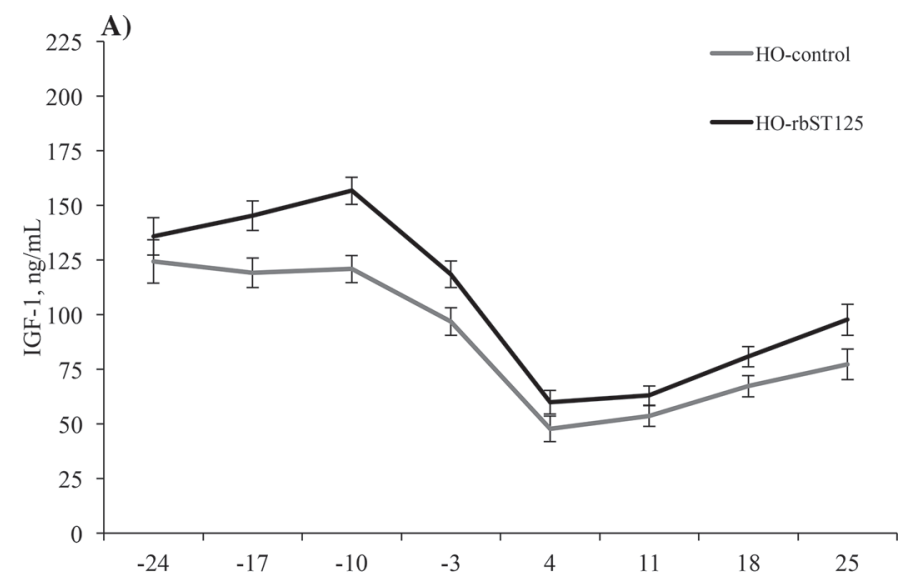

B)

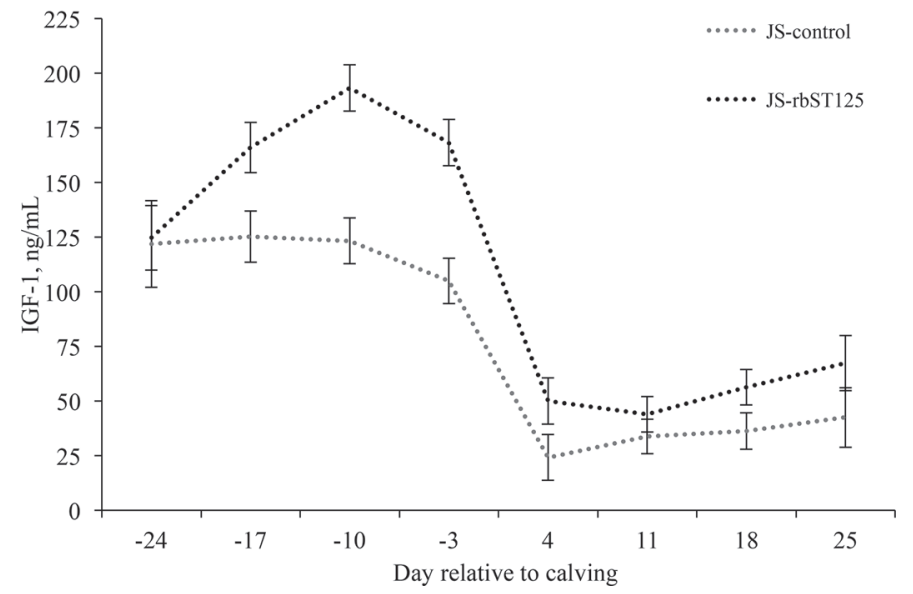

Figure 2. Insulin-like growth factor 1 (IGF-1) concentration of (A) Holstein (HO), and (B) Jersey (JS) cows according to treatment and day relative to calving. Treatments: control $=$ cows received no treatment; rbST125 = cows received $125 \mathrm{mg}$ of recombinant bST every 7 d from -21 to $21 \mathrm{~d}$ relative to calving. Prepartum period: Treatment, $P<0.01$; day relative to calving, $P<0.01$; interaction between treatment and day relative to calving, $P<0.01$; herd, $P<0.01$; and interaction between treatment and herd, $P=0.14$. Postpartum period: Treatment, $P<0.01$; day relative to calving, $P<0.01$; interaction between treatment and day relative to calving, $P=0.98$; herd, $P<$ 0.01 ; and interaction between treatment and herd, $P=0.58$. Results are reported as $\mathrm{LSM} \pm \mathrm{SEM}$. 
Finally, the percentage of cows removed from the herd within $60 \mathrm{~d}$ postpartum was not $(P=0.31)$ different between rbST125 and control treatments (Table 3 ).

\section{Milk Yield and Milk Components}

Milk yield in the first $30 \mathrm{~d}$ postpartum was $(P<$ 0.01) higher for rbST125 cows than for control cows (Table 4$)$. Milk fat percentage was not $(P=0.79)$ affected by treatment, but there was a tendency $(P=$ 0.08 ) for the interaction between treatment and herd to affect the milk fat content because HO-control cows had reduced milk fat percentage compared with JS-control cows, whereas no differences in milk fat percentage were observed between HO-rbST125 and
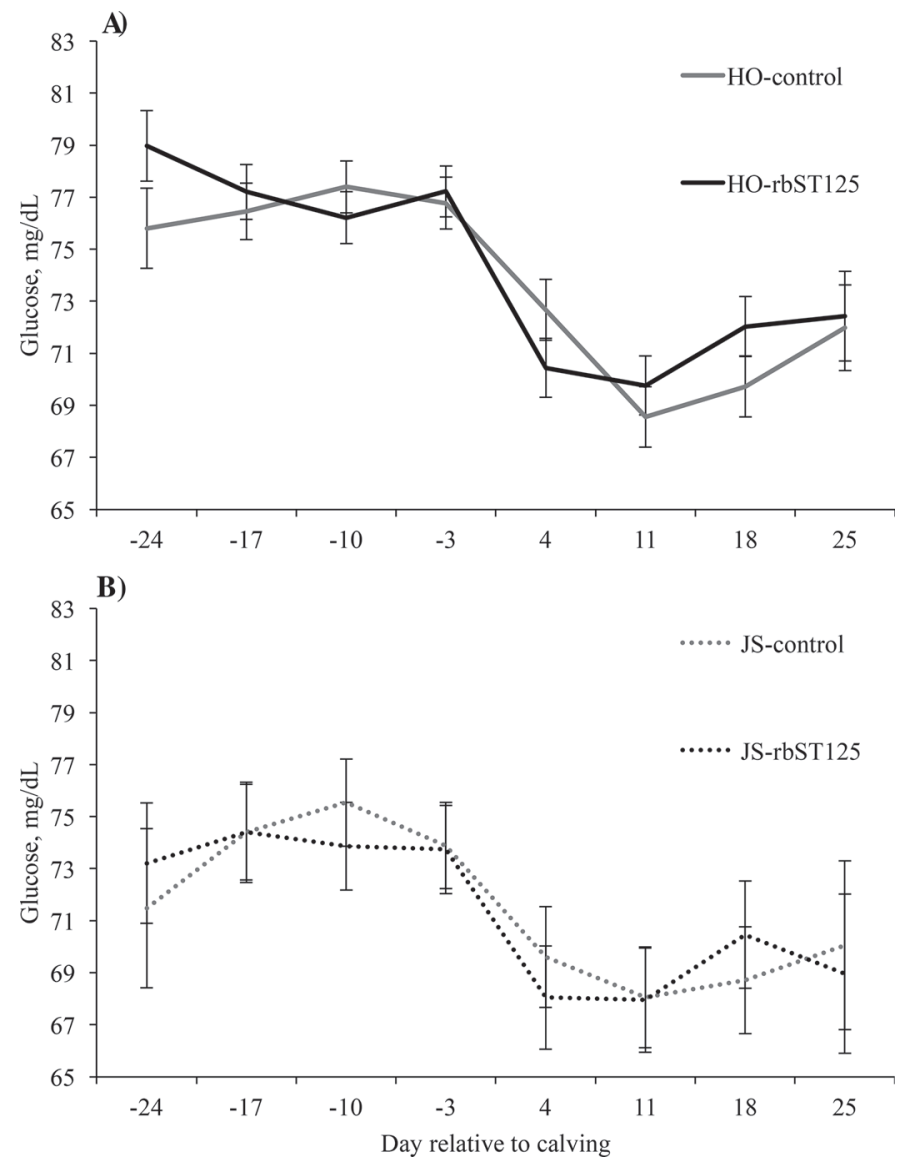

Figure 3. Glucose concentration of (A) Holstein (HO), and (B) Jersey (JS) cows according to treatment and day relative to calving. Treatments: control $=$ cows received no treatment; $\operatorname{rbST} 125=$ cows received $125 \mathrm{mg}$ of recombinant bST every $7 \mathrm{~d}$ from -21 to $21 \mathrm{~d}$ relative to calving. Prepartum period: Treatment, $P=0.56$; day relative to calving, $P=1.00$; interaction between treatment and day relative to calving, $P=0.17$; herd, $P<0.01$; and interaction between treatment and herd, $P=0.71$. Postpartum period: Treatment, $P=0.81$; day relative to calving, $P<0.01$; interaction between treatment and day relative to calving, $P=0.02$; herd, $P=0.18$; and interaction between treatment and herd, $P=0.86$. Results are reported as LSM \pm SEM.
JS-rbST125 cows (Table 4). Milk fat yield was $(P<$ $0.01)$ greater for rbST125 cows than for control cows (Table 4). The interaction between treatment and herd affected $(P=0.03)$ milk fat yield because, among $\mathrm{HO}$ cows, those treated with rbST during the periparturient period had greater milk fat yield, but among JS cows, treatment with rbST did not affect yield of fat (Table 4$)$. Milk protein percentage was $(P<0.01)$ reduced for rbST125 cows compared with control cows, but treatment did not $(P=0.28)$ affect milk protein yield (Table 4$)$. Energy-corrected milk was $(P<0.01)$ higher for rbST125 cows than for control cows (Table 4). The interaction between treatment and herd tended

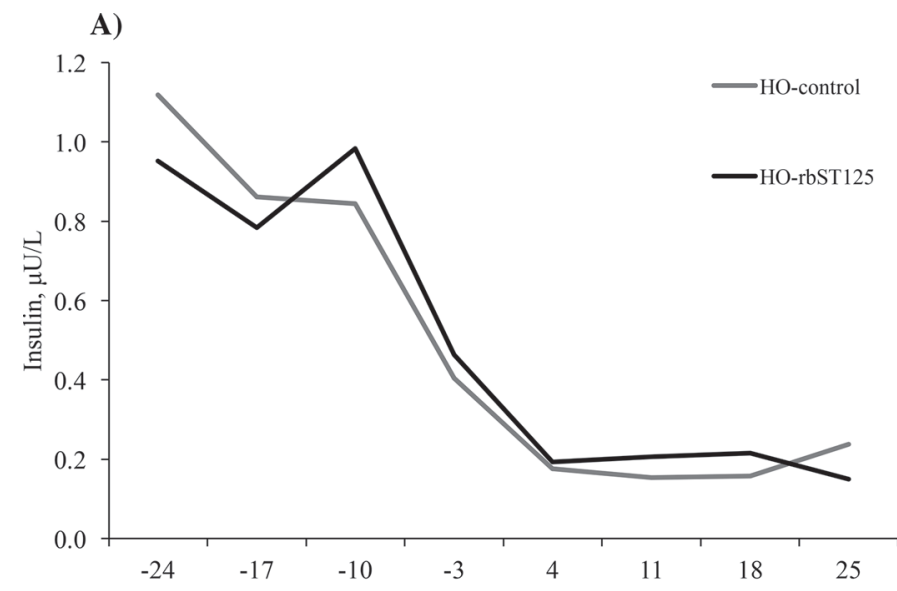

B)

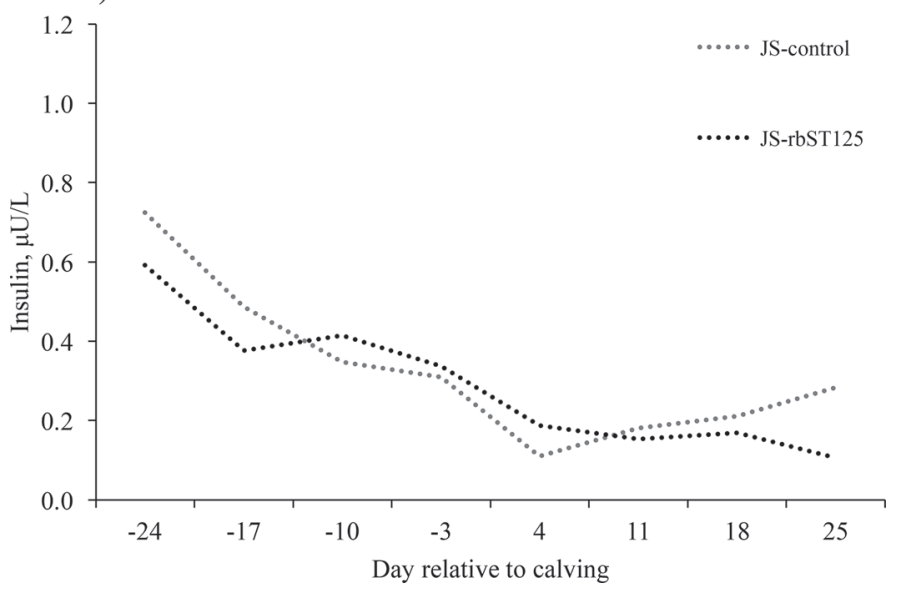

Figure 4. Insulin concentration of (A) Holstein (HO), and (B) Jersey (JS) cows according to treatment and day relative to calving. Treatments: control $=$ cows received no treatment; $\operatorname{rbST} 125=$ cows received $125 \mathrm{mg}$ of recombinant bST every $7 \mathrm{~d}$ from -21 to $21 \mathrm{~d}$ relative to calving. Prepartum period: Treatment, $P=0.89$; day relative to calving, $P<0.01$; interaction between treatment and day relative to calving, $P=0.32$; herd, $P<0.01$; and interaction between treatment and herd, $P=0.81$. Postpartum period: Treatment, $P=0.69$; day relative to calving, $P=0.79$; interaction between treatment and day relative to calving, $P=0.09$; herd, $P=0.39$; and interaction between treatment and herd, $P=0.54$. Results reported are the back transformed values of the LSM of the $\log _{10}$ analysis. 
$(P=0.08)$ to affect yield of ECM because HO-rbST125 cows had greater ECM yield than HO-control cows, but ECM yield was not different between JS-rbST125 and JS-control cows (Table 4). Treatment with rbST $\operatorname{did} \operatorname{not}(P=0.15)$ affect linear SCC within the first 30 DIM (Table 4).

\section{Reproductive Parameters}

Reproductive parameters are depicted in Table 5 . The likelihood of cows receiving the first postpartum AI at detected estrus was not different $(P=0.36)$ between treatments. The large difference $(P<0.01)$ in percentage of cows receiving the first postpartum AI at detected estrus between herds $(\mathrm{HO}=2.7 \%$ vs. JS $=$ $90.3 \%)$ reflects their different management strategies. The interval from calving to first postpartum AI was not $(P=0.60)$ affected by treatment. The likelihood of pregnancy after the first postpartum AI was not different between treatments (first pregnancy exam, $P$ $=0.23$; second pregnancy exam, $P=0.22$ ). The likelihood of pregnancy loss between the first and second pregnancy exams after the first postpartum AI was not $(P=0.83)$ affected by treatment.

The likelihood of cows receiving the second postpartum $\mathrm{AI}$ at detected estrus $(P=0.83)$ and the DIM at second postpartum AI $(P=0.60)$ were not affected by treatment. Treatment did not affect the likelihood of

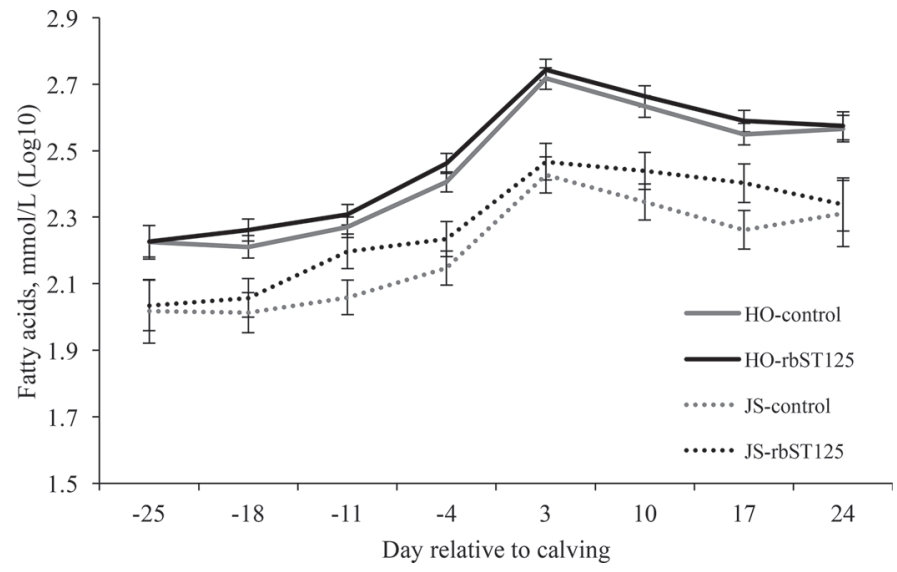

Figure 5. Fatty acid concentration of Holstein (HO) and Jersey (JS) cows according to treatment, day relative to calving, and herd. Treatments: control $=$ cows received no treatment; $\operatorname{rbST} 125=$ cows received $125 \mathrm{mg}$ of recombinant bST every $7 \mathrm{~d}$ from -21 to $21 \mathrm{~d}$ relative to calving. Prepartum period: Treatment, $P=0.14$; day relative to calving, $P<0.01$; interaction between treatment and day relative to calving, $P=0.81$; herd, $P<0.01$; and interaction between treatment and herd, $P=0.52$. Postpartum period: Treatment, $P=0.20$; day relative to calving, $P<0.01$; interaction between treatment and day relative to calving, $P=0.80$; herd, $P<0.01$; and interaction between treatment and herd, $P=0.45$. Results are reported as LSM $( \pm \mathrm{SEM})$ of the $\log _{10}$ analysis. pregnancy after the second postpartum AI (first pregnancy exam, $P=0.51$; second pregnancy exam, $P=$ $0.73)$. The likelihood of pregnancy loss between the first and second pregnancy exams after the second postpartum AI did not $(P=0.33)$ differ between treatments. The hazard of pregnancy up to $150 \mathrm{~d}$ postpartum was not affected by treatment $(P=0.14$; adjusted hazard ratio for pregnancy of control vs. rbST125 cows $=1.14$, $95 \% \mathrm{CI}=0.96,1.36)$ or by the interaction between treatment and herd $(P=0.94)$. The mean $( \pm$ SEM $)$ intervals from calving to pregnancy were $109.8 \pm 3.2$, $110.4 \pm 3.1,100.5 \pm 2.4$, and $105.9 \pm 2.5$ for $\mathrm{HO}$ control, HO-rbST125, JS-control, and JS-rbST125 cows, respectively. The median intervals from calving

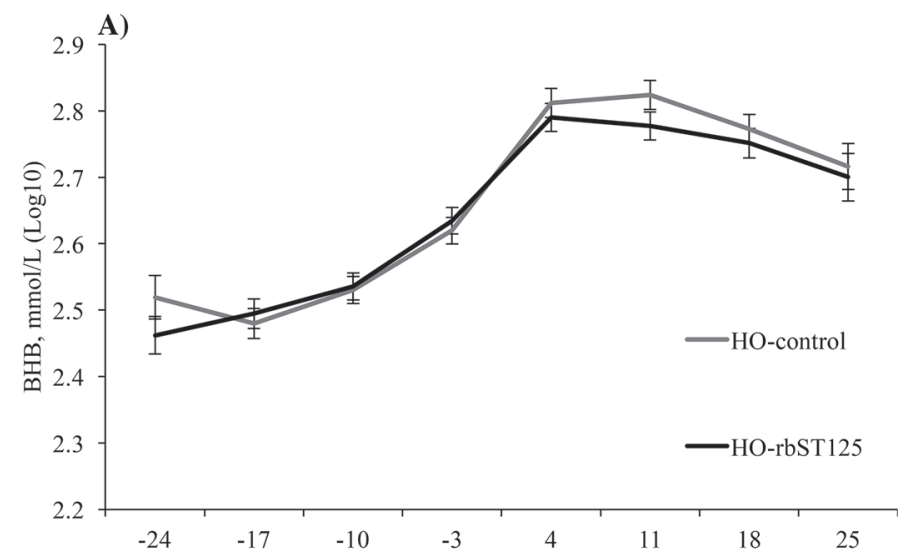

B)

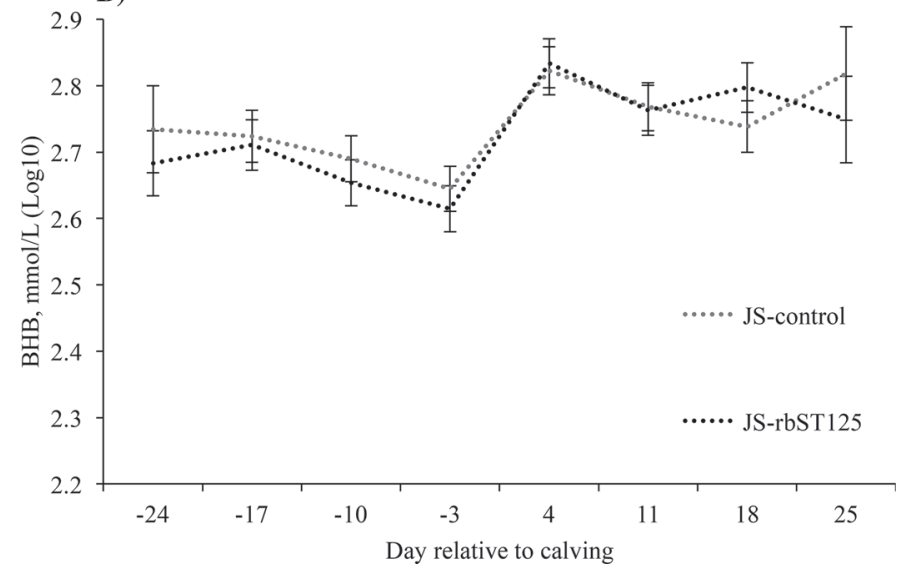

Figure 6. Concentration of BHB of (A) Holstein (HO), and (B) Jersey (JS) cows according to treatment and day relative to calving. Treatments: control $=$ cows received no treatment; $\operatorname{rbST} 125=$ cows received $125 \mathrm{mg}$ of recombinant bST every $7 \mathrm{~d}$ from -21 to $21 \mathrm{~d}$ relative to calving. Prepartum period: Treatment, $P=0.39$; day relative to calving, $P=0.33$; interaction between treatment and day relative to calving, $P=0.74$; herd, $P<0.01$; and interaction between treatment and herd, $P=0.54$. Postpartum period: Treatment, $P=0.36$; day relative to calving, $P<0.01$; interaction between treatment and day relative to calving, $P=0.68$; herd, $P=0.66$; and interaction between treatment and herd, $P=0.33$. Results are reported as LSM $( \pm \mathrm{SEM})$ of the $\log _{10}$ analysis. 


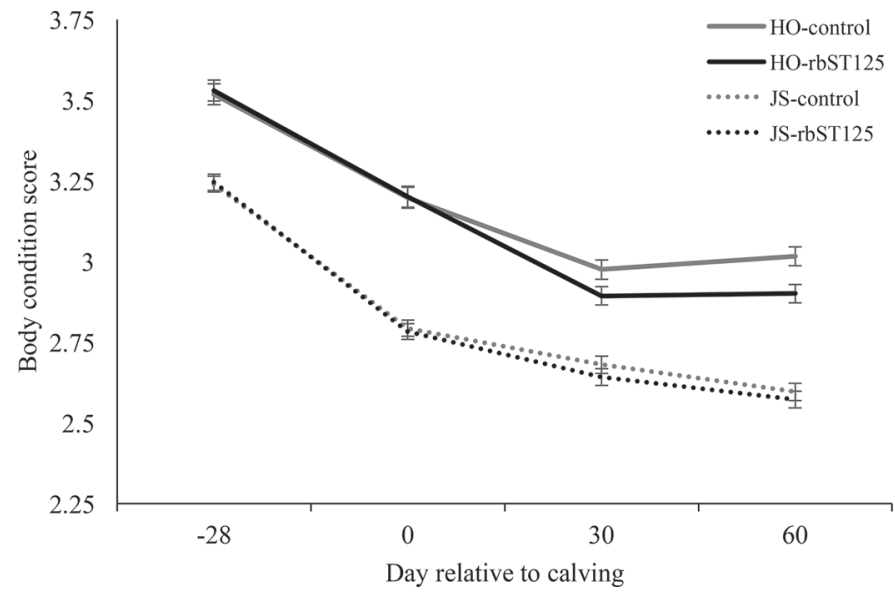

Figure 7. Body condition score of Holstein (HO) and Jersey (JS) cows according to treatment, day relative to calving, and herd. Treatments: control $=$ cows received no treatment; $\operatorname{rbST} 125=$ cows received $125 \mathrm{mg}$ of recombinant bST every $7 \mathrm{~d}$ from -21 to $21 \mathrm{~d}$ relative to calving. Prepartum period: Treatment, $P=0.93$; day relative to calving, $P<0.01$; interaction between treatment and day relative to calving, $P=0.62$; herd, $P<0.01$; and interaction between treatment and herd, $P=0.85$. Postpartum period: Treatment, $P=0.01$; day relative to calving, $P=0.01$; interaction between treatment and day relative to calving, $P=0.74$; herd, $P<0.01$; and interaction between treatment and herd, $P=0.17$. Results are reported as LSM \pm SEM.

to establishment of pregnancy were $112,112,96$, and $107 \mathrm{~d}$ for HO-control, HO-rbST125, JS-control, and JSrbST125 cows, respectively.

\section{DISCUSSION}

Decoupling of the somatotropic axis during the transition from late gestation to early lactation is characterized by a rapid increase in GH concentration and a rapid decrease in IGF-1 concentration, as a consequence of the downregulation of expression of hepatic GH 1- $\alpha$ receptors (GHR1A) in the face of NEB (Rhoads et al., 2004; Lucy, 2008). The decreased IGF-1 concentration reduces the IGF-1 negative feedback on GH release by the pituitary gland and maintains elevated GH concentrations (Lucy, 2008; Romero et al., 2012). Although treatment with rbST resulted in greater IGF-1 concentrations during the prepartum and postpartum periods, the differences in IGF-1 concentrations between rbST125 and control cows were greater during the prepartum period, suggesting that from $\mathrm{d}-17$ to -3 relative to calving, the $\mathrm{GH}$ receptor system was coupled but from d 4 to 25 relative to calving, the GH receptor system was decoupled. Downregulation of hepatic GHR1A mRNA starts at approximately $5 \mathrm{~d}$ before parturition, reaching a nadir $5 \mathrm{~d}$ postpartum (Lucy, 2004). Treatment of cows with 87.5 and $125 \mathrm{mg}$ of rbST weekly from -21 to $28 \mathrm{~d}$ relative to calving increased the hepatic expression of mRNA for GHR1A at -7 and $7 \mathrm{~d}$ relative to calving (Silva et al., 2017), suggesting that exogenous GH may upregulate GHR1A and possibly expedite the recoupling of the somatotropic axis. Although it is not clear how treatment with rbST may have expedited the recoupling of the somatotropic axis, the recoupling in the postpartum period depends on energy balance and insulin concentrations (Butler et al., 2003; Lucy, 2008). Glucose and insulin concentrations were increased in periparturient dairy cows treated with $\mathrm{rbST}$ when blood samples were collected daily or every other day around the time of parturition (Putnam et al., 1999; Gulay et al., 2004; Gohary et al., 2014). In the current experiment, glucose and insulin concentrations were not different between cows treated with rbST and control cows but blood samples were collected weekly, which might have limited our ability to detect differences.

In the current experiment, weekly treatment of periparturient dairy cows with $125 \mathrm{mg}$ of rbST from -21 to $21 \mathrm{~d}$ relative to calving reduced the incidence of uterine disorders. Function of PMNL from cows diagnosed with retained fetal membranes and metritis is impaired during the immediate prepartum and postpartum periods (Cai et al., 1994; Kimura et al., 2002; Hammon et al., 2006). Metabolic challenges and, to a lesser extent, endocrine changes associated with parturition have been implicated in the impairment of PMNL function (Kimura et al., 1999; Hammon et al., 2006). Although less explored, it is also possible that the decoupling of the somatotropic axis during the periparturient period of dairy cows, and the consequent reduced IGF-1 concentration, may impair immune function. Immune cells produce GH and IGF-1 and express receptors for GH and IGF-1 (Merimee et al., 1989), which have been shown to modulate the innate and adaptive immune responses (Kooijman et al., 1996; Weigent, 1996; Ryu et al., 2000; Smaniotto et al., 2004). For example, treatment of malnourished humans with GH increased PMNL phagocytosis (Kotzmann et al., 2003) and GH replacement therapy of GH-deficient humans increased release of superoxide anion by neutrophils (Reinisch et al., 1996) and increased the concentrations of granulocyte colony-stimulating factor and blood neutrophil counts (Sohmiya et al., 2005). Insulin-like growth factor 1 modulates immune cell proliferation (Merimee et al., 1989), chemotaxis (Tapson et al., 1988), T-cell activation (Johnson et al., 1992), inhibition of lymphocytes and neutrophils, apoptosis (Baserga et al., 1997; Kooijman et al., 2002), and natural killer (NK) cell cytotoxicity (Kooijman et al., 1992). Moreover, IGF-1 increases B-cell differentiation, maturation, and proliferation (Gibson et al., 1993; Funk et al., 1994). Insulin growth factor-1 may also modulate the inflammatory response by inhibiting the production of tumor necrosis 
DAIRY COW, SOMATOTROPIN, HEALTH, AND PERFORMANCE

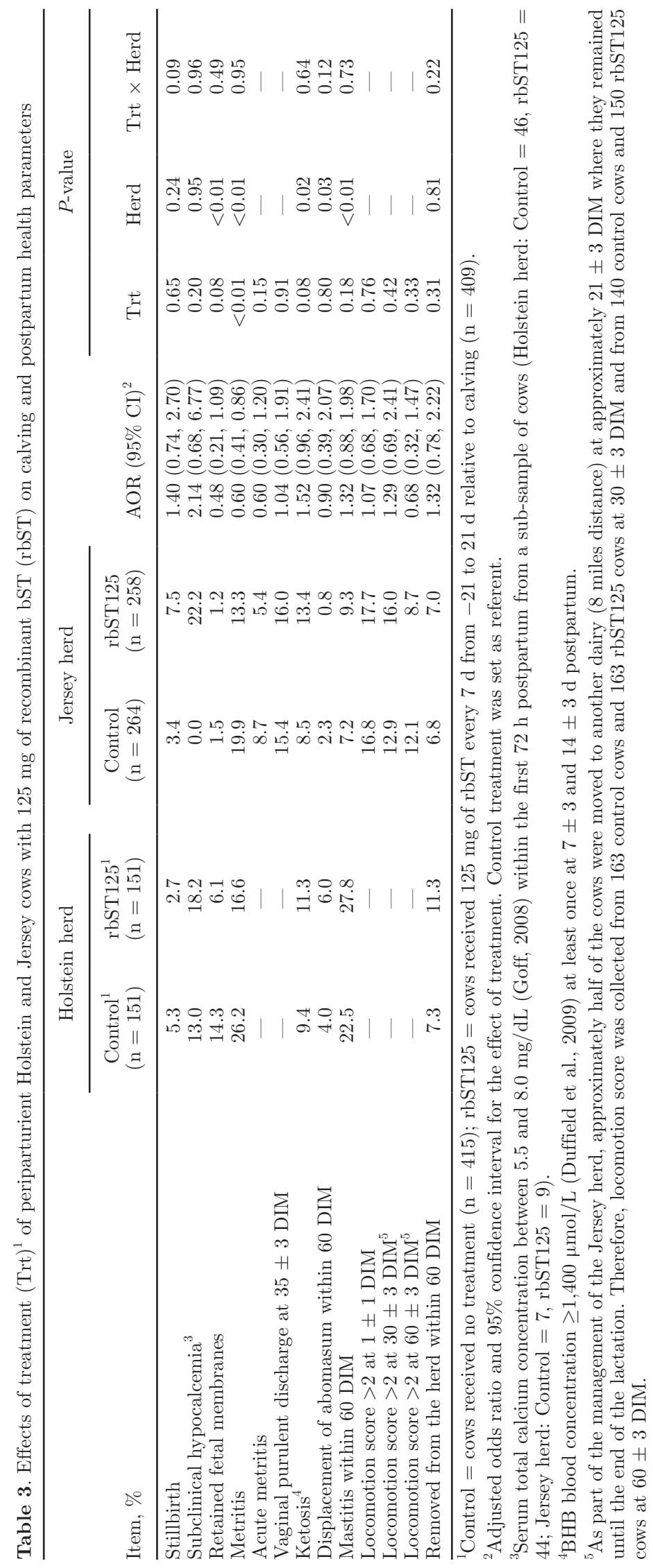


Table 4. Effects of treatment (Trt) ${ }^{1}$ of periparturient Holstein and Jersey cows with $125 \mathrm{mg}$ of recombinant bST (rbST) on milk yield and quality in the first $30 \mathrm{~d}$ postpartum $(\mathrm{LSM} \pm \mathrm{SEM})$

\begin{tabular}{|c|c|c|c|c|c|c|c|}
\hline \multirow[b]{2}{*}{ Item } & \multicolumn{2}{|c|}{ Holstein herd } & \multicolumn{2}{|c|}{ Jersey herd } & \multicolumn{3}{|c|}{$P$-value } \\
\hline & $\begin{array}{c}\text { Control }^{1} \\
(\mathrm{n}=151)\end{array}$ & $\begin{array}{l}\operatorname{rbST} 125^{1} \\
(\mathrm{n}=151)\end{array}$ & $\begin{array}{c}\text { Control } \\
(\mathrm{n}=264)\end{array}$ & $\begin{array}{l}\text { rbST125 } \\
(\mathrm{n}=258)\end{array}$ & Trt & Herd & Trt $\times$ Herd \\
\hline Milk yield, $\mathrm{kg} / \mathrm{d}$ & $31.8 \pm 0.8$ & $34.9 \pm 0.8$ & $22.3 \pm 0.6$ & $23.4 \pm 0.6$ & $<0.01$ & $<0.01$ & 0.13 \\
\hline Fat, $\%$ & $4.42^{\mathrm{x}} \pm 0.08$ & $4.56^{\mathrm{x}} \pm 0.08$ & $4.69^{\mathrm{y}} \pm 0.05$ & $4.59^{\mathrm{x}} \pm 0.06$ & 0.79 & 0.03 & 0.08 \\
\hline Fat, kg/d & $1.33^{\mathrm{a}} \pm 0.04$ & $1.51^{\mathrm{b}} \pm 0.04$ & $1.02^{\mathrm{c}} \pm 0.03$ & $1.06^{\mathrm{c}} \pm 0.03$ & $<0.01$ & $<0.01$ & 0.03 \\
\hline Protein, \% & $3.72 \pm 0.05$ & $3.54 \pm 0.05$ & $3.74 \pm 0.04$ & $3.61 \pm 0.04$ & $<0.01$ & 0.35 & 0.52 \\
\hline Protein, kg/d & $1.11 \pm 0.03$ & $1.17 \pm 0.03$ & $0.81 \pm 0.02$ & $0.83 \pm 0.02$ & 0.28 & $<0.01$ & 0.43 \\
\hline ECM, kg/d & $35.5^{\mathrm{a}} \pm 1.0$ & $39.4^{\mathrm{b}} \pm 1.0$ & $26.7^{\mathrm{c}} \pm 0.6$ & $27.8^{\mathrm{c}} \pm 0.6$ & $<0.01$ & $<0.01$ & 0.08 \\
\hline Linear SCC & $4.43 \pm 0.19$ & $4.37 \pm 0.19$ & $3.53 \pm 0.12$ & $3.26 \pm 0.12$ & 0.15 & $<0.01$ & 0.49 \\
\hline
\end{tabular}

${ }^{\mathrm{a}-\mathrm{c}}$ Within herd and within row, numbers with different lowercase letters differ $(P \leq 0.01)$.

${ }^{\mathrm{x}, \mathrm{y}}$ Between herds and within row, numbers with different lowercase letters differ $(P<0.05)$.

${ }^{1}$ Control $=$ cows received no treatment $(\mathrm{n}=415) ; \operatorname{rbST} 125=$ cows received $125 \mathrm{mg}$ of rbST every $7 \mathrm{~d}$ from -21 to $21 \mathrm{~d}$ relative to calving $(\mathrm{n}$ $=409)$.

factor- $\alpha$, IL-1 $\beta$, and IL-6 (Guo et al., 2014). In a recent experiment, weekly treatment of periparturient Holstein cows with $125 \mathrm{mg}$ of rbST from -21 to $28 \mathrm{~d}$ relative to calving increased GH and IGF-1 concentrations, improved PMNL function (e.g., phagocytosis, oxidative burst, expression of L-selectin), increased IgG antiovalbumin concentration, and reduced the incidence of metritis (Silva et al., 2015). The greatest differences in PMNL function and IgG anti-ovalbumin concentration between rbST treated and control cows were observed from -7 to $0 \mathrm{~d}$ relative to calving, when cows had received at least 2 treatments of $125 \mathrm{mg}$ of rbST (Silva et al., 2015). Thus, it is reasonable to speculate that the rbST-induced increase in the prepartum concentration of IGF-1 observed in the current experiment may have improved immune function during the periparturient period, which may have reduced the incidence of re- tained fetal membranes and metritis. Despite the fact that the difference in incidence of acute metritis between JS-control and JS-rbST125 was not statistically significant, the numerical reduction in the incidence of acute metritis was $37.9 \%$ among JS-rbST125, which is similar to the statistically significant reduction in the incidence of metritis in both herds ( $\mathrm{HO}=36.6 \%$, JS $=33.2 \%$ ). This leads us to speculate that the sample size was insufficient to detect a difference in the incidence of acute metritis between treatments. No effect of $\mathrm{rbST}$ treatment on the incidence of vaginal purulent discharge was observed among JS cows. This might be a consequence of the aggressive antimicrobial and supportive (e.g., antiinflammatory) therapy provided to the JS cows diagnosed with retained fetal membranes, metritis, and acute metritis in the collaborating herd. Farm personnel were blinded to treatments but because

Table 5. Effect of treatment (Trt) ${ }^{1}$ of periparturient Holstein and Jersey cows with $125 \mathrm{mg}$ of recombinant bST (rbST) on reproductive parameters

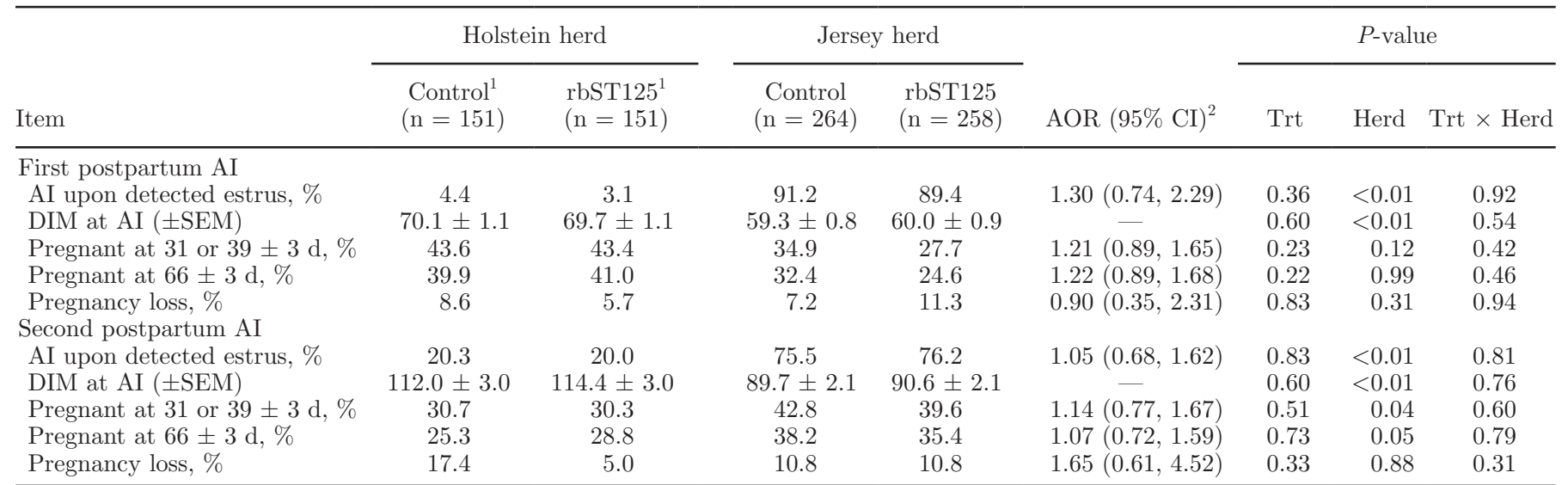

${ }^{1}$ Control $=$ cows received no treatment $(\mathrm{n}=415) ;$ rbST125 = cows received $125 \mathrm{mg}$ of rbST every $7 \mathrm{~d}$ from -21 to $21 \mathrm{~d}$ relative to calving $(\mathrm{n}$ $=409$ ).

${ }^{2}$ Adjusted odds ratio and $95 \%$ confidence interval for the effect of treatment. Control treatment was set as referent. 
untreated cows did not receive a placebo, it was not possible to blind study personnel. Nonetheless, on the days when cows were being examined by study personnel, treatment of the cows was unknown and rbST treatment was not given. Because this was a large experiment with several hundred cows, we are confident that bias during examination did not occur.

Gohary et al. (2014) did not observe improvements in the uterine health of dairy cows treated with $325 \mathrm{mg}$ of rbST every $14 \mathrm{~d}$ during the prepartum period. Although concentrations of GH and IGF-1 start to increase shortly after rbST treatment of lactating cows, peak concentrations of GH and IGF-1 are observed approximately $7 \mathrm{~d}$ after the first treatment, and a sharp decrease in concentrations of GH and IGF-1 is observed by 8 to $9 \mathrm{~d}$ after treatment (Bilby et al., 2006; Rivera et al., 2010). Thus, it is possible that rbST given at a 14-d interval (Gohary et al., 2014) resulted in several cows going through the periparturient period while GH and IGF-1 concentrations were low, limiting its benefits to immune cells. Excessive increase in GH concentration resulting from a 325-mg rbST dose may have compromised the immune function of cows in the study by Gohary et al. (2014) because cultures of peripheral immune cells (Zarkesh-Esfahani et al., 2000) and lymphocytes (Bozzola et al., 1988-1989) with different concentrations of GH resulted in a quadratic dose effect on cytokine production, STAT5 activation (Zarkesh-Esfahani et al., 2000), and lymphocyte proliferation (Bozzola et al., 1988-1989). Finally, in the study by Gohary et al. (2014), cows may have received only 1 treatment with rbST during the prepartum period, which may not have exposed cows to a sustained high IGF-1 concentration.

Although the incidence of subclinical hypocalcemia was not different between treatments, the number of cows used to evaluate this outcome might have been insufficient to detect a difference. Eppard et al. (1996) demonstrated that cows treated with $500 \mathrm{mg}$ of rbST every $14 \mathrm{~d}$ from -28 to $14 \mathrm{~d}$ relative to calving and fed cationic diets containing elevated Ca concentration had increased hydroxyproline, a common marker of bone reabsorption. Although those authors suggested that rbST may have increased bone calcium reabsorption, calcium concentrations were not increased by rbST treatment, despite the reduced milk yield among rbSTtreated cows (Eppard et al., 1996).

Weekly treatment of periparturient cows with 125 $\mathrm{mg}$ of $\mathrm{rbST}$ tended to increase the incidence of ketosis from 4 to $17 \mathrm{~d}$ postpartum. In the subsample of cows from which samples were collected weekly from -21 to $21 \mathrm{~d}$ relative to calving, plasma fatty acid and BHB concentrations were not affected by treatment. Other researchers, however, demonstrated that treatment of periparturient dairy cows with rbST reduced the incidence of ketosis (Gulay et al., 2007) and tended to decrease the plasma BHB concentration (Silva et al., 2015) in the postpartum period. In the current experiment, rbST treatment decreased BCS during the postpartum period and increased yield of ECM by approximately 4 and $1 \mathrm{~kg} / \mathrm{d}$ in the first 30 DIM among Holstein and Jersey cows, respectively. The slight increase in incidence of ketosis in the face of greater mobilization of body fat depot and yield of ECM suggests that cows treated with rbST may have been more adapted to greater metabolic challenges. Treatment of dairy cows with rbST increases the uptake and oxidation of fatty acids by peripheral tissues, which may lead to a reduction in substrate for hepatic BHB production (Bauman, 1992; Putnam et al., 1999). Silva et al. (2017) demonstrated that prepartum hepatic mRNA expression for APOA5 and APOB100, apolipoproteins components of very low density lipoprotein molecules involved in the transport of triglycerides from the liver to the bloodstream, were increased among cows treated weekly with 87.5 and $125 \mathrm{mg}$ of rbST from -21 to 28 d relative to calving. Furthermore, postpartum liver mRNA expression for APOA5 and ACOX1, enzymes involved in fatty acid transport and $\beta$-oxidation, were increased among cows treated with 87.5 and $125 \mathrm{mg}$ of rbST, respectively (Silva et al., 2017). Consequently, rbST treatment during the periparturient period may improve fatty acid oxidation and transport by the liver.

Incidences of displacement of abomasum, mastitis, and lameness, and percentage of cows removed from the herd within $60 \mathrm{~d}$ postpartum were not affected by treatment. Similarly, Vallimont et al. (2001) and Gohary et al. (2014) did not observe an effect of rbST treatment on incidences of displacement of abomasum and mastitis when cows were treated with 500 or 325 $\mathrm{mg}$ of rbST, respectively, during the prepartum period. Although Gulay et al. (2007) did not observe a difference in incidence of displacement of abomasum between rbST-treated and control cows, rbST treatment during the periparturient period reduced the incidence of mastitis. As mentioned previously, rbST-induced increases in the concentrations of GH and IGF-1 improved PMNL function and IgG concentration during the periparturient period (Silva et al., 2015), which may also improve immune response to intramammary pathogens.

Yields of milk, fat, and ECM were greater for rbST125 cows than for control cows. The rbST-induced increase in GH and IGF-1 concentrations may have improved productive responses through increased lipolysis, nutrient prioritization to the mammary gland, and proliferation and maintenance of epithelial cells of the mammary gland (Bauman, 1992). Milk content of protein was greater for control cows than for rbST125 cows, which is likely to be a consequence of a dilution effect 
of increased milk yield in rbST125 cows since total milk protein yield was not different between treatments. In general, treatment of prepartum and periparturient cows with rbST has been shown to increase yields of milk and ECM (Putnam et al., 1999; Gulay et al., 2003, 2004; Gohary et al., 2014).

Reproductive performance was not improved by rbST treatment during the periparturient period, despite significant improvements in uterine health and higher postpartum IGF-1 concentrations in rbST125 cows. Retained fetal membranes and metritis are associated with increased days to first postpartum insemination and decreased pregnancy per AI (Coleman et al., 1985; LeBlanc et al., 2002). Consistent with our results, Gohary et al. (2014) did not demonstrate improvements in reproductive performance of cows treated with rbST during the prepartum period. One may suggest that the improved uterine health during the early postpartum period was counteracted by more severe NEB of rbST125 cows, characterized by reduced BCS postpartum and increased yield of ECM (Lucy et al., 1991; Nebel and McGilliard, 1993). It is unlikely, however, that energy balance was significantly lower in rbST-treated cows because they had greater IGF1 concentrations during the postpartum period. It is more likely that aggressive diagnosis and treatment of cows with retained fetal membranes and metritis with antimicrobial and antiinflammatory drugs and the use of ovulation synchronization protocols and fixed-time AI may have confounded the results regarding reproductive performance.

\section{CONCLUSIONS}

Treatment of periparturient dairy cows with $125 \mathrm{mg}$ of rbST weekly from -21 to $21 \mathrm{~d}$ relative to calving may be used to reduce the incidence of retained fetal membranes and metritis. Furthermore, treatment of periparturient dairy cows with $125 \mathrm{mg}$ of rbST may improve yield of ECM with minimal consequences to the concentrations of metabolites. Reduced incidences of retained fetal membranes and metritis may lead to the reduced utilization of antimicrobials and antiinflammatory drugs, which, coupled with increased yield of ECM, may improve profitability of dairy herds. Although the increased yield of ECM and mobilization of fat depots among periparturient cows treated with rbST suggest that they may have had more negative energy balance postpartum, rbST-treated cows had greater IGF-1 concentrations, which is associated with less negative energy balance. Additional research is warranted to determine the effects of rbST treatment of prepartum versus periparturient cows with reduced doses at 7 -d intervals. This would include carryover ef- fects of rbST on DMI and NEB of the cow as well as effects on health, developmental, immune, and endocrine responses of the calf.

\section{ACKNOWLEDGMENTS}

The authors thank the owners, managers, and staff of the collaborating dairies (Jersey herd and Emerald II Dairy, Emerald, WI).

\section{REFERENCES}

Ballou, M. A., R. C. Gomes, S. O. Juchem, and E. J. DePeters. 2009 Effects of dietary supplemental fish oil during the peripartum period on blood metabolites and hepatic fatty acid compositions and total triacylglycerol concentrations of multiparous Holstein cows. J. Dairy Sci. 92:657-669.

Baserga, R., A. Hongo, M. Rubini, M. Prisco, and B. Valentinis. 1997. The IGF-1 receptor in cell growth, transformation, and apoptosis. Biochim. Biophys. Acta 1332:105-126.

Bauman, D. E. 1992. Bovine somatotropin: Review of an emerging animal technology. J. Dairy Sci. 75:3432-3451.

Bell, A. W., and D. E. Bauman. 1997. Adaptations of glucose metabolism during pregnancy and lactation. J. Mammary Gland Biol. Neoplasia 2:265-278.

Bertics, S. J., R. R. Grummer, C. Cardorniga-Valino, and E. E. Stoddard. 1992. Effect of prepartum DMI on liver triglyceride concentration and early lactation. J. Dairy Sci. 75:1914-1922.

Bilby, T. R., A. Sozzi, M. M. Lopez, F. Silvestre, A. D. Ealy, C. R. Staples, and W. W. Thatcher. 2006. Pregnancy, bovine somatotropin, and dietary n-3 fatty acids in lactating dairy cows: I. ovarian, conceptus, and growth hormone-insulin-like growth factor system responses. J. Dairy Sci. 89:3360-3374.

Bozzola, M., A. Valtorta, A. Moretta, D. Montagna, R. Maccario, and G. R. Burgio. 1988-1989. Modulating effect of growth hormone $(\mathrm{GH})$ on PHA-induced lymphocyte proliferation. Thymus $12: 157-165$.

Burton, J. L., M. E. Kehrli Jr., S. Kapil, and R. L. Horst. 1995. Regulation of L-selectin and CD18 on bovine neutrophils by glucocorticoids: Effects of cortisol and dexamethasone. J. Leukoc. Biol. $57: 317-325$.

Butler, S. T., A. L. Bork, S. H. Pelton, R. P. Radcliff, M. C. Lucy, and W. R. Butler. 2003. Insulin restores hepatic growth hormone (GH) responsiveness during lactation-induced negative energy balance in dairy cattle: effects on expression of insulin-like growth factor-I and GH receptor 1A. J. Endocrinol. 176:205-217.

Cai, T. Q., P. G. Weston, L. A. Lund, B. Brodie, D. J. McKenna, and W. C. Wagner. 1994. Association between neutrophil functions and periparturient disorders in cows. Am. J. Vet. Res. 55:934-943.

Coleman, D. A., W. V. Thayne, and R. A. Dailey. 1985. Factors affecting reproductive performance of dairy cows. J. Dairy Sci. 68:1793-1803.

Contreras, G. A., W. Raphael, S. A. Mattmiller, J. Gandy, and L. M. Sordillo. 2012. Nonesterified fatty acids modify inflammatory response and eicosanoid biosynthesis in bovine endothelial cells. J. Dairy Sci. 95:5011-5023.

Duffield, T. F., K. D. Lissemore, B. W. McBride, and K. E. Leslie. 2009. Impact of hyperketonemia in early lactation dairy cows on health and production. J. Dairy Sci. 92:571-580.

Eppard, P. J., J. J. Veenhuizen, W. J. Cole, P. G. Comens-Keller, G. F. Hartnell, R. L. Hintz, L. Munyakazi, P. K. Olsson, R. H. Sorbet, T. C. White, C. A. Baile, R. J. Collier, J. P. Goff, and R. L. Horst. 1996. Effect of bovine somatotropin administered to periparturient dairy cows on the incidence of metabolic disease. J. Dairy Sci. 79:2170-2181

Ferguson, J. D., D. T. Galligan, and N. Thomsen. 1994. Principal descriptors of body condition score in HO cows. J. Dairy Sci. 77:2695-2703. 
Funk, P. E., P. W. Kincade, and P. L. Witte. 1994. Native associations of early hematopoietic stem cells and stromal cells isolated in bone marrow cell aggregates. Blood 83:361-369.

Gibson, L. F., D. Piktel, and K. S. Landreth. 1993. Insulin-like growth factor-1 potentiates expansion of interleukin-7 dependent pro-B cells. Blood 82:3005-3011.

Goff, J. P. 2008. The monitoring, prevention, and treatment of milk fever and subclinical hypocalcemia in dairy cows. Vet. J. 176:50-57.

Gohary, K., S. J. LeBlanc, K. D. Lissemore, M. W. Overton, M. Von Massow, and T. F. Duffield. 2014. Effect of prepartum administration of recombinant bovine somatotropin on health and performance of lactating dairy cows. J. Dairy Sci. 97:6231-6241.

Grummer, R. R. 1995. Impact of changes in organic nutrient metabolism on feeding the transition dairy cow. J. Anim. Sci. 73:28202833.

Grummer, R. R., D. G. Mashek, and A. Hayirli. 2004. Dry matter intake and energy balance in the transition period. Vet. Clin. North Am. Food Anim. Pract. 20:447-470.

Gulay, M. S., A. N. Garcia, M. J. Hayen, C. J. Wilcox, and H. H. Head. 2003. Responses of Holstein cows to a low dose of somatotropin (bST) prepartum and postpartum. J. Dairy Sci. 86:3195-3205.

Gulay, M. S., M. J. Hayen, M. Liboni, T. I. Belloso, C. J. Wilcox, and H. H. Head. 2004. Low doses of bovine somatotropin during the transition period and early lactation improves milk yield, efficiency of production, and other physiological responses of Holstein cows. J. Dairy Sci. 87:948-960.

Gulay, M. S., M. Liboni, M. J. Hayen, and H. H. Head. 2007. Supplementing Holstein cows with low doses of bovine somatotropin prepartum and postpartum reduces calving-related diseases. J. Dairy Sci. 90:5439-5445.

Guo, J., D. Zheng, W. Li, H. Li, A. Zhang, and Z. Li. 2014. Insulinlike growth factor 1 treatment of MSCs attenuates inflammation and cardiac dysfunction following MI. Inflammation 37:2156-2163.

Hammon, D. S., I. M. Evjen, T. R. Dhiman, J. P. Goff, and J. L. Walters. 2006. Neutrophil function and energy status in Holstein cows with uterine health disorders. Vet. Immunol. Immunopathol. 113:21-29

Hayirli, A., R. R. Grummer, E. Nordheim, P. Crump, D. K. Beede, M. J. VandeHaar, and L. H. Kilmer. 1998. A mathematical model for describing DMI of transition dairy cows. J. Dairy Sci. 81(Suppl. 1):296. (Abstr.)

Heemskerk, V. H., M. A. R. C. Daemen, and W. A. Buurman. 1999 Insulin-like growth factor-1 (IGF-1) and growth hormone (GH) in immunity and inflammation. Cytokine Growth Factor Rev. 10:5-14.

Johnson, E. W., L. A. Jones, and R. W. Kozak. 1992. Expression and function of insulin-like growth factor receptors on anti-CD3activated human T lymphocytes. J. Immunol. 148:63-71.

Kehrli, M. E., Jr., B. J. Nonnecke, and J. A. Roth. 1989a. Alterations in bovine neutrophil function during the periparturient period. Am. J. Vet. Res. 50:207-214.

Kehrli, M. E., Jr., B. J. Nonnecke, and J. A. Roth. 1989b. Alterations in bovine lymphocyte function during the periparturient period. Am. J. Vet. Res. 50:215-220.

Kelton, D. F., K. D. Lissemore, and R. E. Martin. 1998. Recommendations for recording and calculating the incidence of selected clinical diseases of dairy cattle. J. Dairy Sci. 81:2502-2509.

Kimura, K., J. P. Goff, and M. E. Kehrli Jr. 1999. Effects of the presence of the mammary gland on expression of neutrophil adhesion molecules and myeloperoxidase activity in periparturient dairy cows. J. Dairy Sci. 82:2385-2392.

Kimura, K., J. P. Goff, M. E. Kehrli Jr., and T. A. Reinhardt. 2002. Decreased neutrophil function as a cause of retained placenta in dairy cattle. J. Dairy Sci. 85:544-550.

Kimura, K., T. A. Reinhardt, and J. P. Goff. 2006. Parturition and hypocalcemia blunts calcium signals in immune cells of dairy cattle. J. Dairy Sci. 89:2588-2595.

Kooijman, R., A. Coppens, and E. Hooghe-Peters. 2002. IGF-I inhibits spontaneous apoptosis in human granulocytes. Endocrinology $143: 1206-1212$.
Kooijman, R., E. L. Hooghe-Peters, and R. Hooghe. 1996. Prolactin, growth hormone and insulin-like growth factor-1 in the immune system. Adv. Immunol. 63:377-454.

Kooijman, R., M. Willems, G. T. Rijkers, A. Brinkman, S. C. van Buul-Offers, C. J. Heijnen, and B. J. Zegers. 1992. Effects of insulin-like growth factors and growth hormone on the in vitro proliferation of T lymphocytes. J. Neuroimmunol. 38:95-104.

Kotzmann, H., A. Schmidt, P. Lercher, E. Schuster, G. Geyer, H. Frisch, W. H. Hörl, G. Mayer, and A. Luger. 2003. One-year growth hormone therapy improves granulocyte function without major effects on nutritional and anthropometric parameters in malnourished hemodialysis patients. Nephron Clin. Pract. 93:75-82.

Lalman, D. L., J. E. Williams, B. W. Hess, M. G. Thomas, and D. H. Keisler. 2000. Effect of dietary energy on milk production and metabolic hormones in thin, primiparous beef heifers. J. Anim. Sci. 78:530-538.

LeBlanc, S. J. 2010. Monitoring metabolic health of dairy cattle in the transition period. J. Reprod. Dev. 56:S29-35.

LeBlanc, S. J., K. Leslie, T. Duffield, K. Bateman, G. P. Keefe, J. S. Walton, and W. H. Johnson. 2002. Defining and diagnosing postpartum clinical endometritis and its impact on reproductive performance in dairy cows. J. Dairy Sci. 85:2223-2236.

LeBlanc, S. J., K. D. Lissemore, D. F. Kelton, T. F. Duffield, and K. E. Leslie. 2006. Major advances in disease prevention in dairy cattle. J. Dairy Sci. 89:1267-1279.

Lucy, M. C. 2004. Mechanisms linking the somatotropic axis with insulin: Lessons from the postpartum dairy cow. Vol 64. New Zealand Society of Animal Production, Hamilton, New Zealand.

Lucy, M. C. 2008. Functional differences in the growth hormone and insulin-like growth factor axis in cattle and pigs: implications for post-partum nutrition and reproduction. Reprod. Domest. Anim. 43(Suppl 2):31-39

Lucy, M. C., C. R. Staples, F. M. Michel, and W. W. Thatcher. 1991. Energy balance and size and number of ovarian follicles detected by ultrasonography in early postpartum dairy cows. J. Dairy Sci. 74:473-482.

McDougall, S., R. Macaulay, and C. Compton. 2007. Association between endometritis diagnosis using a novel intravaginal device and reproductive performance in dairy cattle. Anim. Reprod. Sci. 99:9-23.

Merimee, T. J., M. B. Grant, C. M. Broder, and L. L. Cavalli-Sforza. 1989. Insulin-like growth factor secretion by human B-lymphocytes: A comparison of cells from normal and pygmy subjects. J. Clin. Endocrinol. Metab. 69:978-984.

Moreira da Silva, F. C. Burvenich, A. M. Massart Leën, and L. Brossé. 1998. Assessment of blood neutrophil oxidative burst activity in dairy cows during the period of parturition. Anim. Sci. 67:421-426.

Nebel, R. L., and M. L. McGilliard. 1993. Interactions of high milk yield and reproductive performance in dairy cows. J. Dairy Sci. $76: 3257-3268$.

NRC. 2001. Nutrient Requirements of Dairy Cattle. 7th ed. Natl Acad. Press, Washington, DC.

Oetzel, G. R. 2004. Monitoring and testing dairy herds for metabolic disease. Vet. Clin. North Am. Food Anim. Pract. 20:651-674.

Orth, R. 1992. Sample day and lactation report. In DHIA 200 Fact Sheet A-2. Dairy Records Processing Center, Ames, IA.

Peel, C. J., and D. E. Bauman. 1987. Somatotropin and lactation. J. Dairy Sci. 70:474-486.

Pocius, P. A., and J. H. Herbein. 1986. Effects of in vivo administration of growth hormone on milk production and in vitro hepatic metabolism in dairy cattle. J. Dairy Sci. 69:713-720.

Putnam, D. E., G. A. Varga, and H. M. Dann. 1999. Metabolic and production responses to dietary protein and exogenous somatotropin in late gestation dairy cows. J. Dairy Sci. 82:982-995.

Reinisch, N., P. Schratzberger, G. Finkenstedt, C. M. Kahler, and C. J. Wiedermann. 1996. Superoxide anion release from neutrophils in growth hormone deficient adults before and after replacement therapy with recombinant human growth hormone. Naunyn Schmiedebergs Arch. Pharmacol. 354:369-373.

Rhoads, R. P., J. W. Kim, B. J. Leury, L. H. Baumgard, N. Segoale, S. J. Frank, D. E. Bauman, and Y. R. Boisclair. 2004. Insulin increas- 
es the abundance of the growth hormone receptor in liver and adipose tissue of periparturient dairy cows. J. Nutr. 134:1020-1027.

Rivera, F., C. Narciso, R. Oliveira, R. L. Cerri, A. Correa-Calderón, R. C. Chebel, and J. E. Santos. 2010. Effect of bovine somatotropin $(500 \mathrm{mg}$ ) administered at ten-day intervals on ovulatory responses, expression of estrus, and fertility in dairy cows. J. Dairy Sci. 93:1500-1510.

Romero, C. J., E. Pine-Twaddell, D. I. Sima, R. S. Miller, L. He, F. Wondisford, and S. Radovick. 2012. Insulin-like growth factor 1 mediates negative feedback to somatotroph GH expression via POU1F1/CREB binding protein interactions. Mol. Cell. Biol. 32:4258-4269.

Ryu, H., J. H. Lee, K. S. Kim, S. M. Jeong, P. H. Kim, and H. T. Chung. 2000. Regulation of neutrophil adhesion by pituitary growth hormone accompanies tyrosine phosphorylation of Jak2, p125FAK, and paxillin. J. Immunol. 165:2116-2123.

Shook, G. E. 1982. Approaches to summarizing somatic cell count which improve interpretability. Page 150 in Proc. 21st Annu. Mtg. Natl. Mastitis Counc., Arlington, VA. National Mastitis Council, Madison, WI.

Silva, P. R. B., K. S. Machado, D. N. Lobão Da Silva, G. N. Moraes, D. H. Keisler, and R. C. Chebel. 2015. Effects of recombinant bovine somatotropin during the periparturient period on innate and adaptive immune responses, systemic inflammation, and metabolism of dairy cows. J. Dairy Sci. 98:4449-4464.

Silva, P. R. B., W. J. Weber, B. A. Crooker, and R. C. Chebel. 2017. Hepatic mRNA expression for genes related to somatotropic axis, glucose and lipid metabolisms, and inflammatory response of periparturient dairy cows treated with recombinant bovine somatotropin. J. Dairy Sci. 100. 10.3168/jds.2016-12135.
Smaniotto, S., M. M. Ribeiro-Carvalho, M. Dardenne, W. Savino, and V. de Mello-Coelho. 2004. Growth hormone stimulates the selective trafficking of thymic CD4+CD8- emigrants to peripheral lymphoid organs. Neuroimmunomodulation 11:299-306.

Sohmiya, M., I. Kanazawa, and Y. Kato. 2005. Effect of recombinant human GH on circulating granulocyte colony-stimulating factor and neutrophils in patients with adult GH deficiency. Eur. J. Endocrinol. 152:211-215.

Sprecher, D. J., D. E. Hostetler, and J. B. Kaneene. 1997. A lameness scoring system that uses posture and gait to predict dairy cattle reproductive performance. Theriogenology 47:1179-1187.

Tapson, V. F., M. Boni-Schnetzler, P. F. Pilch, D. M. Center, and J. S. Berman. 1988. Structural and functional characterization of the human $\mathrm{T}$ lymphocyte receptor for insulin-like growth factor I in vitro. J. Clin. Invest. 82:950-957.

Vallimont, J. E., G. A. Varga, A. Arieli, T. W. Cassidy, and K. A Cummins. 2001. Effects of prepartum somatotropin and monensin on metabolism and production of periparturient Holstein dairy cows. J. Dairy Sci. 84:2607-2621.

Weigent, D. A. 1996. Immunoregulatory properties of growth hormone and prolactin. Pharmacol. Ther. 69:237-257.

Zarkesh-Esfahani, S. H., O. Kolstad, R. A. Metcalfe, P. F. Watson, S. von Laue, S. Walters, A. Revhaug, A. P. Weetman, and R. J. Ross. 2000. High-dose growth hormone does not affect proinflammatory cytokine (tumor necrosis factor-alpha, interleukin-6, and interferon-gamma) release from activated peripheral blood mononuclear cells or after minimal to moderate surgical stress. J. Clin. Endocrinol. Metab. 85:3383-3390. 